\title{
Arthrorhachis Hawle \& Corda, 1847 (Agnostida) in the Prague Basin (Barrandian area, Czech Republic) revisited
}

\author{
Petr BUdil, OldŘICH FATKA, PETR KOLÁŘ \& MARTIn DAVID
}

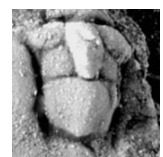

\begin{abstract}
The agnostid Arthrorhachis Hawle \& Corda, 1847 from the Prague Basin (type area of its occurrence, including type species of the genus) is revised. The taxonomic position of all earlier established type specimens is clarified. All available material, including recently collected specimens, is described and discussed. The glabellar impressions are described for the first time on material from the Barrandian area. The stratigraphical distribution of the two established species, A. tarda (Barrande, 1846) and A. pragensis (Přibyl \& Vaněk, 1968) is evaluated. Although Arthrorhachis belongs to the latest agnostids, its representatives are locally common in the dark coloured siltstones of the Zahorany, Bohdalec and especially Králův Dvůr formations (upper Sandbian-upper Katian interval). In the Prague Basin, the last specimens of Arthrorhachis seem to persist up to the onset of the Hirnantian glaciation. The classical concept of the so-called "Lejškov facies" characteristic by comparatively abundant agnostids is discussed. $\bullet$ Key words: Agnostida, Upper Ordovician, Prague Basin, Barrandian area, Czech Republic.
\end{abstract}

Budil, P., FATKA, O., KolÁr̆, P. \& DAVID, M. 2011. Arthrorhachis Hawle \& Corda, 1847 (Agnostida) in the Prague Basin (Barrandian area, Czech Republic) revisited. Bulletin of Geosciences 86(4), 707-724 (9 figures, 1 table). Czech Geological Survey, Prague. ISSN 1214-1119. Manuscript received March 14, 2011; accepted in revised form May 31, 2011; published online July 19, 2011; issued November 16, 2011.

Petr Budil, Czech Geological Survey, Klárov 3, Praha 1, CZ-118 21, Czech Republic; petr.budil@ geology.cz•Oldřich Fatka, Department of Geology and Palaeontology, Faculty of Science, Charles University, Albertov 6, Praha 2, CZ-128 43, Czech Republic; fatka@natur.cuni.cz•Petr Kolár̆, Charles University, Botanical Garden, Na Slupi 16, Praha 2, CZ-128 43, Czech Republic - Martin David, Rožmberská 10, Praha 9, CZ-198 00, Czech Republic; ordovik@seznam.cz.

Although the agnostids reached their acme during the "Middle-Late" Cambrian, they are characteristic and comparatively common elements of many Ordovician shelly faunas of peri-Gondwana. However, in the Upper Ordovician, agnostids are generally rare and usually of low taxonomic diversity. The last, but locally still abundant and widespread agnostids, including Arthrorhachis Hawle \& Corda, 1847 are known from the Upper Ordovician of European peri-Gondwana: namely from ATA (Armorican Terrane Assemblage): Italy and Bohemia; Avalonia: South Wales, North Wales, Northern England; Baltica: Norway, Sweden, Denmark, and Poland; Kazakhstania: Kazakhstan, Uzbekistan and Northern China (for palaeogeographical distribution and references see Fig. 9).

So far, no more than seven moderately preserved specimens of $A$. tarda from the Prague Basin have been figured by Pek (1977), Whittington (1950), Šnajdr (1983), and Fortey (1997). Recently re-discovered specimens, originating from classical collections (e.g. Scháry collection at the Harvard University and National Museum Prague) as well as the recently collected material, made possible a new revision of $A$. tarda.

\section{Material and methods}

All studied specimens, with the exception of one cephalon coming from a siliceous nodule, are preserved in soft clayey, slightly calcareous shales and siltstones. Therefore, the internal and external moulds are too fragile for latex casting. Because of the serious risk of possible damage of the material, latex casting has not been realized. However, the external moulds could provide important supplementary information on skeletal morphology. The existing external moulds were studied in detail and some of them are figured. All samples were coated by the ammonium chloride before the photographing.

Terminology. - The morphological terms used by Whittington et al. (1997) are followed, excluding the terminology of 


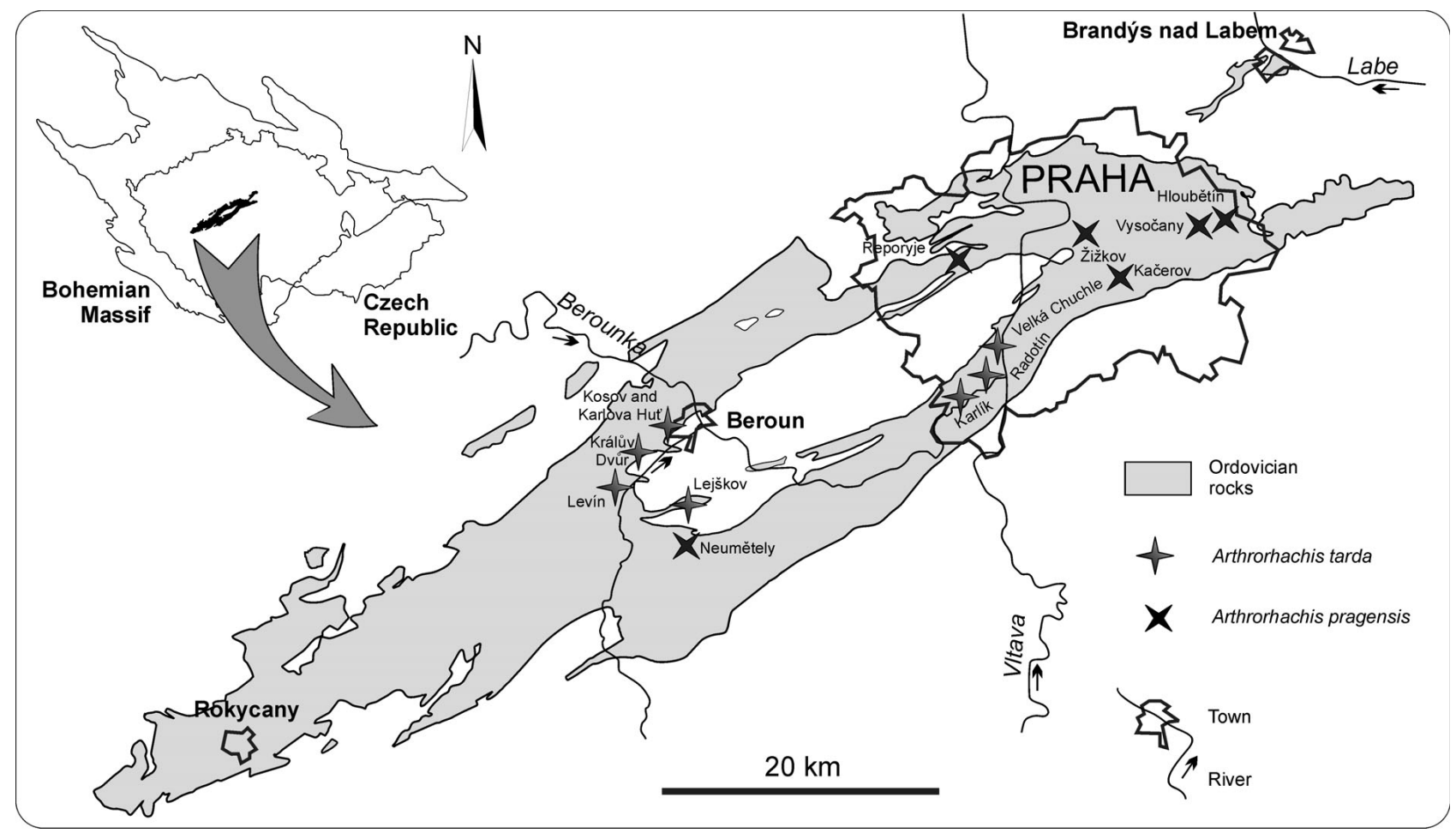

Figure 1. A sketch map of the distribution of the Ordovician rocks in the Barrandian area. The asterisks show the position of localities discussed in the text.

the glabellar impressions, for which the terminology proposed by Fortey (1980) is followed.

Measurements. - Measurements (Table 1) were made using a digital micrometric ruler, supplemented by micrometer eyepiece fitted to a binocular microscope and/or highly enlarged digital image. The morphology and dimensions of the broken and/or covered exoskeletal parts were estimated in cases where the preservation of the mould made such a step possible (for example, the mirroring). All measurements were repeated two times, with the goal to eliminate the possible errors. However, some of the specimens were too poorly preserved to provide relevant data. In such cases, the box in the table was left empty. The following abbreviations have been used:

$\mathrm{Lt}=$ maximum length (sag.) of entire specimen,

Lc $=$ maximum length (sag.) of cephalon,

$\mathrm{Lg}=$ maximum length (sag.) of glabella,

$\mathrm{Wc}=$ maximum width (tr.) of cephalon,

$\mathrm{Wg}=$ maximum width (tr.) of glabella,

$\mathrm{Lp}=$ maximum length (sag.) of pygidium, excluding articulating half-ring,

$\mathrm{La}=$ maximum length (sag.) of pygidial axis, excluding articulating half-ring,

Ls $=$ maximum length (exsag.) of pygidial spine (measured exsag. from estimated pygidial outline),

$\mathrm{Wp}=$ maximum width (tr.) of pygidium,

$\mathrm{Wr}=$ maximum widt (tr.) of pygidial axis.

\section{Systematic part}

Family Metagnostidae Jaekel, 1909

Subfamily Metagnostinae Jaekel, 1909

\section{Genus Arthrorhachis Hawle \& Corda, 1847}

Type species. - Battus tardus Barrande, 1846 from the Králův Dvůr Formation (late Katian; Kralodvorian Regional Stage), Upper Ordovician, Prague Basin, Barrandian area, Czech Republic.

Note on the gender. - The name Arthrorhachis has been widely used as feminine but some authors (e.g. Reed 1931, Kobayashi 1935, Vaněk \& Vokáč 1997) used it as mascu-

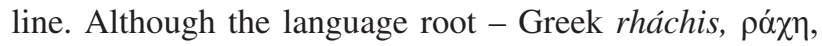

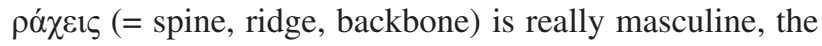
authors of the name used it explicitly as feminine. Because of the priority rule, the only feminine is correct.

Diagnosis. - (After Shergold et al. 1990 and Nielsen 1997, this study.) Metagnostinae with glabellar F3 usually effaced or with straight medial portion; lateral portions curving forwards and outwards. Glabellar tubercle situated immediately behind F3; F2 weakly impressed or effaced. Pygidium typically somewhat transverse, with wide border, usually provided with a pair of small posterolateral spines. Axis very short, occupying less than half of pygidial 
Table 1. Dimensions of Arthrorhachis tarda and Arthrorhachis pragensis.

\begin{tabular}{|c|c|c|c|c|c|c|c|c|c|c|c|c|}
\hline \multicolumn{13}{|c|}{ Dimensions (in mm) of Arthrorhachis tarda and Arthrorhachis pragensis } \\
\hline species & part of specimen & specimen No. & Lt & LC & $\mathrm{Lg}$ & Wc & $\overline{W g}$ & Lp & La & $\mathbf{W p}$ & $\overline{W a}$ & Ls \\
\hline A. tarda & entire specimen & NM L 16534 (neotype, new measurement) & 9.90 & 4.15 & 2.30 & 4.20 & 1.80 & 4.10 & 2.05 & 3.80 & 1.90 & \\
\hline A. tarda & cephalon & CGS PB 600 & & 4.27 & 2.76 & 4.19 & 1.53 & & & & & \\
\hline A. tarda & entire specimen & CGS PB 601 & 9.97 & 4.23 & 2.29 & 4.35 & 1.98 & 3.72 & 1.64 & 4.13 & 1.70 & \\
\hline A. tarda & cephalon & CGS PK 5 & & 4.75 & 3 & 4.21 & 1.82 & & & & & \\
\hline A. tarda & cephalon & CGS XB 177 & & 4.48 & 2.41 & 4.84 & 1.57 & & & & & \\
\hline A. tarda & entire specimen & CGS JV 2489a & 6.25 & 2.87 & 1.76 & 2.99 & 1.22 & 2.44 & 1.28 & 3.01 & 1.41 & 0.30 \\
\hline A. tarda & cephalon + segment & CGS JV 2489b & & 3.80 & 2.40 & 4.25 & 1.46 & & & & & \\
\hline A. tarda & pygidium & CGS JV 2489c & & & & & & 4.51 & 1.74 & 4.23 & 1.95 & \\
\hline A. tarda & cephalon & CGS JV2490a & & 4.27 & 2.46 & 4.73 & 1.64 & & & & & \\
\hline A. tarda & cephalon & CGS JV2490b & & 2.28 & 1.33 & 2.09 & 0.81 & & & & & \\
\hline A. tarda & pygidium & CGS JV2490c & & & & & & 3.40 & 1.45 & 4.28 & & \\
\hline A. tarda & pygidium & CGS JV 2494a & & & & & & 3.48 & 1.55 & 3.80 & 1.87 & \\
\hline A. tarda & pygidium & CGS JV 2494b & & & & & & 3.92 & 1.74 & 3.86 & 1.58 & \\
\hline A. tarda & pygidium & CGS JV 2494c & & & & & & 3.79 & 1.72 & 5.28 & 2.01 & \\
\hline A. tarda & pygidium & CGS JV 2494d & & & & & & 3.50 & 1.82 & 3.75 & 1.83 & \\
\hline A. tarda & entire specimen & MCZ 112322 & 7.75 & 3.45 & 2.15 & 3.80 & 1.80 & 3.50 & 1.55 & 3.80 & 1.71 & \\
\hline A. tarda & entire specimen & MCZ 112323 & 6.10 & 2.80 & 1.55 & 2.95 & 1.20 & 2.75 & 1.05 & 3.00 & 1.10 & \\
\hline A. tarda & cephalon & MCZ 112324a & & 3.00 & 1.95 & 3.10 & 1.30 & & & & & \\
\hline A. tarda & cephalon & MCZ 111324b & & 1.80 & 1.15 & 1.70 & 0.85 & & & & & \\
\hline A. tarda & cephalon & MCZ 112324c & & 3.50 & 2.80 & 3.70 & 1.25 & & & & & \\
\hline A. tarda & entire specimen & MCZ 112325a & 6.50 & 3.25 & 1.90 & 3.20 & 1.20 & 3.10 & 0.80 & 3.20 & $1.2 ?$ & \\
\hline A. tarda & pygidium & MCZ 112325b & & & & & & 3.50 & 1.65 & $3.5 ?$ & 1.50 & 0.20 \\
\hline A. tarda & pygidium & MCZ 114040 & & & & & & 3.80 & 1.95 & 4.20 & 1.90 & \\
\hline A. $\operatorname{tarda}$ & cephalon & NM L 4501 & & & 1.80 & 4.00 & 1.30 & & & & & \\
\hline A. $\operatorname{tarda}$ & cephalon & NM L 5145 & & 3.90 & 2.85 & 4.50 & 1.60 & & & & & \\
\hline A. tarda & cephalon & NM L 16535 & & 4.70 & 2.50 & 4.50 & 2.15 & & & & & \\
\hline A. tarda & cephalon & NM L 16536 & & 3.50 & 1.95 & 3.60 & 1.50 & & & & & \\
\hline A. tarda & pygidium & NM L 16537 & & & & & & 3.80 & 1.90 & 4.65 & 2.30 & \\
\hline A. tarda & pygidium & NM L 16538 & & & & & & 4.30 & 1.80 & 4.80 & 2.00 & 0.25 \\
\hline A. tarda & entire specimen & NM L 40852 & 10.01 & 4.80 & 2.41 & 5.60 & 2.15 & 4.70 & 2.00 & 5.00 & 2.20 & 0.35 \\
\hline A. tarda & cephalon & NM L 40853 & & 3.20 & 1.90 & & 1.20 & & & & & \\
\hline A. tarda & pygidium & NM L 40854 & & & & & & 2.80 & 1.50 & 3.10 & 1.40 & \\
\hline A. tarda & cephalon & NM L 40855 & & 5.10 & 2.50 & 5.30 & 2.20 & & & & & \\
\hline A. tarda & cephalon & NM L 40856 & & 3.80 & 2.50 & 5.00 & 2.30 & & & & & \\
\hline A. tarda & cephalon & NM L 40857 & & 4.00 & 2.51 & 5.80 & 2.10 & & & & & \\
\hline A. tarda & cephalon & NM L 40858 & & 2.80 & 1.80 & 2.30 & 1.00 & & & & & \\
\hline A. $\operatorname{tarda}$ & pygidium & NM L 40859 & & & & & & 5.10 & 1.85 & 4.95 & 1.75 & \\
\hline A. pragensis & pygidium & CGS JV 6 (holotype, new measurement) & & & & & & 3.09 & 1.41 & 3.15 & 1.09 & 1.02 \\
\hline A. pragensis & pygidium & CGS JV 2501 (counterpart of holotype) & & & & & & 3.09 & 1.38 & 3.20 & 1.03 & 0.91 \\
\hline A. pragensis & cephalon & CGS JV 2502 (JV 7 in Pek, pl. 1, obr. 8) & & 2.44 & 1.44 & 1.82 & 0.84 & & & & & \\
\hline A. pragensis & pygidium & CGS JV 2498 & & & & & & 4.05 & 1.86 & 2.95 & 1.19 & 0.65 \\
\hline A. pragensis & cephalon & CGS JV 2499 & & 2.66 & 1.69 & 1.71 & 0.83 & & & & & \\
\hline A. pragensis & pygidium & CGS JV 2500 & & & & & & 3.07 & 1.43 & 2.93 & 1.30 & 0.57 \\
\hline A. pragensis & cephalon & CGS MŚ 11545a & & 3.94 & 2.22 & 3.75 & 1.47 & & & & & \\
\hline A. pragensis & pygidium & CGS MŠ 11545b & & & & & & & & 3.23 & 1.49 & \\
\hline A. pragensis & cephalon & CGS MŠ $11545 b$ & & 3.93 & 2.40 & 3.57 & 1.46 & & & & & \\
\hline A. pragensis & cephalon & NM L 20022 & & 4.20 & 2.80 & 3.60 & 1.45 & & & & & \\
\hline A. pragensis & cephalon & NM L 20466 & & 4.00 & 3.20 & 2.50 & 1.47 & & & & & \\
\hline
\end{tabular}

length, tapering rearwards; posterior lobe typically shorter than remaining portion of axis, and commonly provided with more or less indistinct terminal node. Axial node may be present but often preserved on upper exoskeletal surface only. Upper surface of the exoskeleton may be smooth or covered by tiny anastomozing raised lines forming polygonal or irregularly circular reticulation.

\section{Species affiliated. - See Nielsen (1997, 1999).}

Stratigraphic occurrence. - After Nielsen (1997, 1999): Tremadoc to Arenig (= ?lower Floian to upper Katian), ?Hirnantian after Kielan (1960).

Remarks. - We follow Fortey (1980) in restricting Trinodus to the holotype of its type species, T. agnostiformis M'Coy, 1846, and possibly also few other specimens from its type locality (see below). This step was based on the observation, that the type specimen of the type species (figured also by Whittington 1950, pl. 68, figs 1-3) shows none of the most critical features used for the identification of any metagnostid genus (see also Fortey 1997). The concept of Fortey (1980) has been widely accepted by Fortey \& Owens (1987), Ahlberg (1989), Romano \& Owen (1993), Hammann \& Leone (1997), Whittington et al. (1997), Nielsen (1997), Vaněk \& Vokáč (1997), Shaw (2000) and Vaněk \& Valíček (2001), but not by Pek \& Prokop (1984), Pek \& Vaněk (1989) and Bruton \& Nakrem (2005). Owen \& Parkes (2000) consequently studied new material of T. agnostiformis, a poorly preserved pygidium showing a resemblance with the $A$. tarda group, coming from the same horizon as the holotype of T. agnostiformis; they also tentatively affiliated another pygidium, the lectotype of Agnostus limbatus Salter, 1848 and Agnostus trinodus Salter, 


\begin{tabular}{|c|c|c|c|c|c|c|c|c|}
\hline \multicolumn{6}{|c|}{ GLOBAL } & \multicolumn{2}{|c|}{ REGIONAL } & \multirow[b]{2}{*}{$\begin{array}{l}\text { STRATIGRAPHIC } \\
\text { RANGE }\end{array}$} \\
\hline 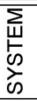 & 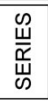 & STAGES & 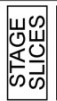 & of & 2 & STAGES & FORMATIONS & \\
\hline \multirow{6}{*}{$\begin{array}{l}z \\
\frac{z}{0} \\
\frac{u}{z} \\
0 \\
0 \\
0 \\
0 \\
0\end{array}$} & \multirow{6}{*}{$\begin{array}{l}a \\
w \\
a \\
a \\
a\end{array}$} & HIRNANTIAN & \begin{tabular}{|l}
$\mathrm{Hi2}$ \\
$\mathrm{Hi1}$
\end{tabular} & 6c & 21 & KOSOVIAN & KOSOV & $\frac{8}{8}$ \\
\hline & & \multirow{3}{*}{ KATIAN } & \begin{tabular}{|l|}
$\mathrm{Ka} 4$ \\
$\mathrm{Ka} 3$
\end{tabular} & $\begin{array}{l}6 b \\
6 a \\
\end{array}$ & \begin{tabular}{|l|}
20 \\
19 \\
18 \\
\end{tabular} & KRALODVORIAN & $\begin{array}{l}\text { KRÁLŮV } \\
\text { DVUUR }\end{array}$ & \multirow{5}{*}{ 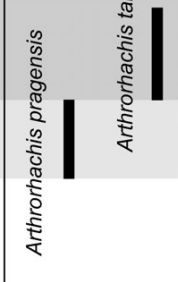 } \\
\hline & & & $\mathrm{Ka} 2$ & 30 & 17 & \multirow{4}{*}{ BEROUNIAN } & & \\
\hline & & & Ka1 & $5 c$ & 16 & & ZAHORANY & \\
\hline & & \multirow{2}{*}{ SANDBIAN } & $\mathrm{Sa} 2$ & $5 b$ & 15 & & LETNÁ & \\
\hline & & & Sa 1 & $5 a$ & 14 & & LIBEN & \\
\hline
\end{tabular}

Figure 2. A stratigraphic occurrence of Arthrorhachis in the Prague Basin.

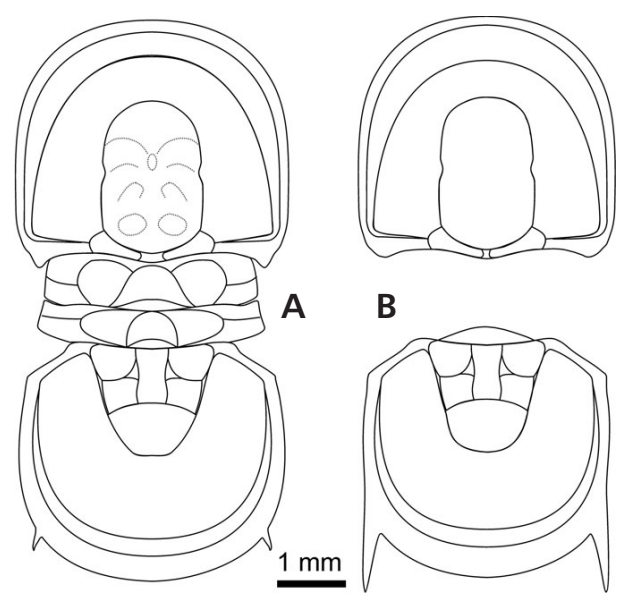

Figure 3. A - a reconstruction of Arthrorhachis tarda (Barrande, 1846). • B - Arthrorhachis pragensis (Přibyl \& Vaněk, 1968).
1848 to the same species. Consequently, they proposed to consider the name Arthrorhachis Hawle \& Corda, 1847 as a subjective junior synonym of Trinodus M'Coy, 1846. Because of morphological differences between T. agnostiformis and A. tarda, they also suggested to retain the name $A r$ throrhachis as a subgenus of Trinodus to encompass the $A$. tarda species group as recognized by Nielsen (1997). This opinion was followed by Turvey (2005), Owens \& Fortey (2009) and Owen \& Romano (2010). However, Jell \& Adrain (2003) listed Arthrorhachis as a valid genus. After a careful evaluation of all arguments, we consider all known material of Trinodus agnostiformis, including the newly published data, as still insufficient and poorly preserved. There is a serious uncertainty if the new specimens (pygidia) of Owen \& Parkes (2000, figs 3c, e) are really conspecific with the holotype specimen of $T$. agnostiformis (cephalon, fig. $3 \mathrm{a}, \mathrm{b}$ ). The other specimen of Owen \& Parkes (2000, fig. 3d) is a lectotype of A. trinodus and A. limbatus (e.g. one specimen represents types for two different species); it is synonymised by Owen \& Parkes (2000, pp. 231, 232) with $T$. agnostiformis. Similarly, there is uncertainty if it is really conspecific with the cephalon. All figured specimens, excluding the holotype of T. agnostiformis, are poorly preserved and plastically deformed. In our opinion, it is not possible to accept these materials as material making possible any proper understanding of original exoskeletal morphology of these forms. New and better-preserved material is still necessary to enable a closer comparison of both species and thus the final solving of the Arthrorhachis/Trinodus relation. Therefore, we consider the Fortey's (1980) proposal as still relevant and reasonable at this stage of knowledge. The rare Sandbian species Trinodus agnostiformis is still too poorly documented to compare with very abundant and often well-preserved Arthrorhachis tarda of Katian age (Owen \& Romano 2010). However, our approach could be a temporary measure, as Zhou
(1987) suggested. The differences between the two differently preserved taxa are difficult to ascertain. To the features discussed already by Owen \& Parkes (2000), it may also be noted that in $T$. agnostiformis, the basal lobes are well separated, whereas they meet in Trinodus tardus ( $c f$. Kielan 1960, p. 62). There are some other potential differences in the course of the axial furrows, which are smoother in T. agnostiformis, and its glabella does not appear slightly constricted at half of its sag. length. T. agnostiformis also shows a shallower cephalic border furrow and possibly flatter pygidial border. However, diagenetic flattening and tectonic deformation could be responsible for most of these differences; because of the poor preservation of $T$. agnostiformis, it is hard to evaluate which of these features is original morphology and which represents the taphonomical artifacts. As noted above, Nielsen (1997) tentatively subdivided Arthrorhachis into two distinct groups: the tarda group and the elspethi group, for which Metagnostus may be restoreds. We follow this subdivision, because of the relatively prominent differences between $A$. tarda and A. elspethi and allied species (see also Fig. 7E herein). Nielsen (1999) stressed a longer pygidial axis, longer posteroaxis, more ridge-like median tubercle and more common terminal axial node in the elspethi group. We can add some minor differences in the construction of the cephalon; a more quadratic cephalic outline with anterolaterally widening cephalic border and a sagitally longer and more prominent cephalic posterior spine in some representatives of the elspethi group.

\section{Arthrorhachis tarda (Barrande, 1846)}

Figures 3A, 4A-C, 5A-I, 6A-L, 7A-C

1846 Battus tardus Barr. - Barrande, p. 35.

1847 Arthrorhachis tarda, nob. - Hawle \& Corda, p. 115, pl. 6, fig. 60 . 
1851 Trinodus tardus? (Bar. sp.) - M'Coy, p. 142, pl. 1E, fig. 9.

1851 Agnostus glabratus n. sp. - Angelin, p. 6, pl. 6, fig. 5.

1852 Agnostus tardus Barr. - Barrande, pp. 913, 914, pl. 49, figs 1-4.

1856 Agnostus tardus Barr. - Barrande, pp. 534, 535.

1883 Agnostus tardus Barr. - Novák, p. 60.

1896 Agnostus cf. galba Billings. - Reed, pp. 408, 409.

1903 Agnostus agnostiformis (M'Coy), 1846. - Reed, pp. 3, 4, pl. 1, fig. 1 .

?1903 Agnostus tardus, Barrande, 1846. - Reed, pp. 7, 8, pl. 1, figs 8, 9 .

1906 Agnostus trinodus Salt. - Olin, p. 72, pl. 4, figs 15, 16.

1922 Agnostus tardus Barrande. - Koliha, p. 5, fig. 3.

1925 Agnostus tardus Barr. - Raymond, p. 7.

1931 Agnostus (Arthrorhachis) tardus Barr. - Reed, p. 2.

1933 Agnostus tardus Barr. - Thoral, p. 148.

1935 Arthrorhachis tardus Hawle \& Corda. - Kobayashi, p. 98, text-fig. 7:7.

1950 Agnostus tardus Barrande. - Termier \& Termier, p. 22 , pl. 137 , fig. 1 .

1950 Trinodus tarda (Hawle \& Corda). - Whittington, p. 535 , pl. 68 , figs $4-6$.

1952 Trinodus tardus Barrande. - Harper, p. 93.

1953 Trinodus tardus Barrande. - Přibyl, p. 43.

1956 Trinodus tardus (Hawle \& Corda). - Kielan, p. 258, pl. 1, figs 4-6.

1960 Trinodus tardus (Barrande, 1846). - Kielan, pp. 59-62, text-fig. 13, pl. 1, figs 6-13.

?1960 Trinodus sp. - Kielan, p. 62, text-fig. 14, pl. 1, fig. 5.

1966 Trinodus tardus (Barrande). - Ingham, pp. 473, 501.

1966 Trinodus tardus (Barrande, 1846). - Havlíček \& Vaněk, pp. 40, 41.

1968 Trinodus tardus (Barrande, 1846). - Whittington, p. 97, pl. 29, figs 8, 10-12, 14-17.

1970 Arthrorhachis tarda (Hawle \& Corda, 1847). Horný \& Bastl, p. 307.

1970 Trinodus tardus (Barrande, 1846). - Horný \& Bastl, p. 308.

1970 Trinodus tardus (Barrande, 1846). - Ingham, pp. 9, 10, pl. 1, figs 1-3.

1971 Trinodus cf. tardus (Barrande). - Dean, pp. 7, 8, pl. 1, figs 3-14.

1971 Trinodus tardus (Barrande). - Dean, p. 8, pl. 1, figs 1, 2.

?1972 Trinodus aff. tardus (Barrande). - Abdullaev, pp. 106, 107, pl. 44, fig. 6.

1972 Trinodus tardus (Barrande). - Tomczykowa et al., p. 36.

1974 Trinodus tardus (Barrande), 1846. - Apollonov, pp. 8-11, pl. 1, figs 1-9.

1977 Trinodus tardus (Barrande, 1846). - Pek, pp. 25, 26, text-fig. 7, pl. 8, fig. 1-1.

aff. 1979 Trinodus aff. tardus (Barrande, 1846). - Bruton \& Owen, figs 2B, 4, 6 . aff. 1980 Trinodus aff. tardus (Barrande, 1846). - Owen \& Bruton, p. 11, pl. 1, figs 1-4.

1980 Trinodus tardus (Barrande). - Price, table 1, p. 841, pl. 107, figs 1-3.

1980 Trinodus tardus (Barrande). - Fortey, pp. 26, 31, 32.

1981 Arthrorhachis cf. tarda Hawle \& Corda, 1847. Owen, p. 11, pl. 1, figs 1-3.

1982 Trinodus tardus (Barrande). - Koroleva, pp. 23, 24, pl. 1, fig. 6.

1983 Arthrorhachis tarda.-S̆najdr, pp. 197, 198, pl. 7, fig. 3.

1984 Trinodus tardus (Barrande, 1846). - Pek \& Prokop, p. 18.

1986 Arthrorhachis cf. tarda. - Zhou \& Dean, pp. 744, 746, 747, pl. 58, figs 3, 4.

1987 Arthrorhachis tarda. - Zhou, figs 3, 7, fig. 3.

1988 Arthrorhachis tarda. - Morris, p. 25.

1989 Arthrorhachis tarda (Barrande, 1846). - Ahlberg, pp. 214-221, figs 2A-I, 3A, B, B: A-I.

1989 Trinodus tardus (Barrande, 1846). - Pek \& Vaněk, pp. 33, 53.

1991 Arthrorhachis tarda (Barrande, 1846). - Leone et al., p. 224 , pl. 5 , fig. 8 .

1997 Arthrorhachis tarda. - Nielsen, pp. 674, 675.

1997 Arthrorhachis tardus. - Vaněk \& Vokáč, p. 24.

1999 Arthrorhachis tarda. - Fatka \& Pek, pp. 381, 382.

1999 Arthrorhachis tarda (Barrande, 1846). - Nielsen, pp. 144, 145.

sic 2000 Arthrorachis tarda (Barrande, 1846). - Shaw, p. 375, pl. 1, fig. 1.

2000 Arthrorhachis tarda. - Owen \& Parkes, pp. 230-232.

2001 Arthrorhachis tarda (Barrande, 1846). - Vaněk \& Valíček, p. 43.

2002 Arthrorhachis tarda. - Villas et al., p. 273.

2008 Trinodus cf. tardus (Barrande). - Owen \& Bruton, Table 1.

Neotype. - The internal mould of a nearly complete specimen plus its external mould, illustrated by Barrande (1852, pl. 49, figs 1, 2) and Pek (1977, pl. 8, fig. 2). The specimen was selected as the lectotype by Přibyl (in Horný \& Bastl 1970) but this chose was questioned by Morris (1980), Fortey (1997) and Owen \& Parkes (2000). The specimen deposited in the type collections of the National Museum, Museum of Natural History, Prague, under No. NM L 16534 (older No. ČD 1812). It is shown here in the Fig. 5A, B. Dimensions of the neotype in $\mathrm{mm}$ : $\mathrm{Lt}=9.9$; $\mathrm{Lc}=4.2 ; \mathrm{Lg}=2.3 ; \mathrm{Wc}=4.2 ; \mathrm{Wg}=1.8 ; \mathrm{Lp}=4.1 ; \mathrm{La}=2.1$; $\mathrm{Wp}=3.8 ; \mathrm{Wa}=1.9 ; \mathrm{Ls}=0.49$. Some measurements differ slightly from those of Pek (1977). This difference is explained by the better equipment used for this study.

Type locality and horizon. - Libomyšl (most likely the classical locality called Lejškov, see discussion on stratigraphy), Králův Dvůr Formation (late Katian; Kralodvorian 
Regional Stage), Upper Ordovician, Prague Basin, Barrandian area, Czech Republic.

Remarks. - Morris (1988, p. 25), Fortey (1997) and Owen $\&$ Parkes (2000) were right in remarking that the selection of the lectotype of A. tarda (Barrande, 1846) by Prribyl (in Horný \& Bastl 1970) was not entirely correct (for discussion, see also Shaw 2000). Přibyl in Horný \& Bastl (1970) used for the designation of the lectotype an almost complete specimen selected from the syntypes, used by Barrande (1852, but not 1846!). Barrande (1846), in his description of Battus tardus explicitly mentioned only a "glabelle" and two segments coming "près Beraun". Unfortunately, Barrande (1846) did not figure the species but provided only a short description. Subsequently, Barrande (1852) published a more detailed description and reconstruction (Barrande 1852, pl. 49, figs 1, 2) of this species, but under different generic affiliation as Agnostus tardus Barr. For this description, Barrande probably used the following newly gathered material: (1) the complete specimen selected as the lectotype by Prribyl in Horný \& Bastl (1970), (2) probably also another complete specimen, which was not discussed so far (see below), (3) three cephala and two pygidia coming from two different localities situated close to Beroun city (= called Beraun in Barrande's time), e.g. the Libomyšl locality and the Köningshoff (= Králův Dvůr) locality. Barrande's (1852) samples share the same stratigraphic horizon with the previously published material of Barrande (1846).

However, any later comparison between the quite vague original type area of Barrande (1846) with the more precisely defined localities by Barrande (1852) is impossible. As discussed above, there is a serious doubt that we do not have at our disposal the authentic original material used for the first description of the species by Barrande (1846). Thus, the position of the lectotype selected by Přibyl (in Horný \& Bastl 1970) is problematical. Because of serious doubts about the authenticity of the original syntypes used by Barrande (1846), we propose here to consider the specimen selected as the lectotype by Přibyl (in Horný \& Bastl 1970) rather as the neotype of Battus tardus Barrande, 1846. We hope that this taxonomical approach will finally solve the doubts about the type specimens of this quite well documented, common and stratigraphically important species. During revision of the type material of this species, another articulated exoskeleton of Agnostus tardus Barr. has been found in the collections of the Natural History Museum, Prague (NML 40852, older No. ČD 1813; figured here on Fig. 5D, E). It could be a part of Barrande's (1852) type material, because of the very close inventory number to the other specimens (ČCD 1812, 1814 and 1815; see Prribyl in Horný \& Bastl 1970, p. 308), and also, because the "Leiskow" locality (= Lejškov in the $19^{\text {th }}$ century writing) is marked on the sample. Following the attached original label, probably derived from the late $19^{\text {th }}$ to the early $20^{\text {th }}$ century, the specimen was originally considered as part of the Barrande's (1852) material (this original designation was subsequently scratched on the label by an unknown person) but the specimen has been never figured and/or discussed. Its position remains unclear but it is not excluded that it belongs to Barrande's (1852) material.

When Morris (1988, p. 25) proposed the provisional separation of the two species - A. tarda and A. convexa (Salter, 1848), based on differences in the length of the pygidial axis (see below in variability chapter) and (legitimately) questioned the status of the lectotype of Battus tardus selected by Přibyl in Horný \& Bastl (1970), he indirectly opened up the possibility, that Battus tardus Barrande, 1846 might be a nomen nudum and that Agnostus trinodus var. ß convexus Salter, 1848 may have a priority. Such replacement of the well-documented species by the comparatively poorly known taxon should be considered as risking the stability of nomenclature. It is also possible to add, that although Barrande (1846) did not figure the species, its description is sufficiently accurate to ensure that Battus tardus Barrande 1846 and Agnostus tardus Barr. sensu Barrande (1852) represent an identical species. Finally, Barrande (1852) himself confirmed this concept.

However, there is a second specimen designated as lectotype of Arthrorhachis tarda; it was figured by Šnajdr (1983, pp. 197, 198, pl. 7, fig. 3). After Owen \& Parkes (2000), Šnajdr (1983) gave a different specimen, an incomplete cranidium NM L 5145 (re-figured here in Fig. 6A), from the Beroun area ("exact locality unknown") as lectotype of Arthrorhachis tarda. These authors remarked that the status of the specimen remains to be clarified. However, the second lectotype discussed was not originally selected by Šnajdr (1983) but already by Přibyl in Horný \& Bastl (1970), on p. 307 as a lectotype of Arthrorhachis tarda (sensu) Hawle \& Corda, 1847. This information was published by Šnajdr (1983, p. 197) but he did not point out these two different concepts (Hawle \& Corda marked their species Arthrorhachis tarda by remark "nobis"), which probably caused the misunderstanding. Přibyl in Horný \& Bastl (1970, p. 307) explicitly mentioned two syntypes of Arthrorhachis tarda (sensu) Hawle \& Corda, 1847: NML 5144 and NM L 5145, of which the last specimen was selected as lectotype. The other specimen, a poorly preserved fragment of cephalon (NM L 5144 ) is figured here in Fig. 6B for the first time. This specimen, similar to the lectotype defined by Přibyl in Horný \& Bastl (1970) comes, without any doubt, from Hawle's collection, and posseses also the quotation " $H$ ", made by black ink directly on the rock piece (a similar marking of Hawle \& Corda's lectotype was discussed by Šnajdr 1983). Both specimens are stored in the collections of the National Museum, Prague and should be considered as the syntypes 
Figure 4. A-C - Arthrorhachis tarda (Barrande, 1846). An excellently preserved cephalon with preserved glabellar muscle insertion areas, specimen C̆GS PK 5a (internal mould). Upper Katian, Králův Dvůr Formation (Tretaspis anderssonni Horizon). PrahaRadotín, highways tunnel excavation. - D - Arthrorhachis pragensis (Přibyl \& Vaněk, 1968). The best preserved cephalon, NM L 20466, figured by Pek \& Prokop (1984), on pl. 1, fig 3 and re-figured by Vaněk \& Vokáč (1997) on pl. 1, fig. 1, coming from the dark, fine-grained siliceous nodule. Bohdalec Formation, exact horizon unknown. Praha-Nová Dubeč, a field between Dubeč and Dolní Počernice. Scale bar represents $1 \mathrm{~mm}$.
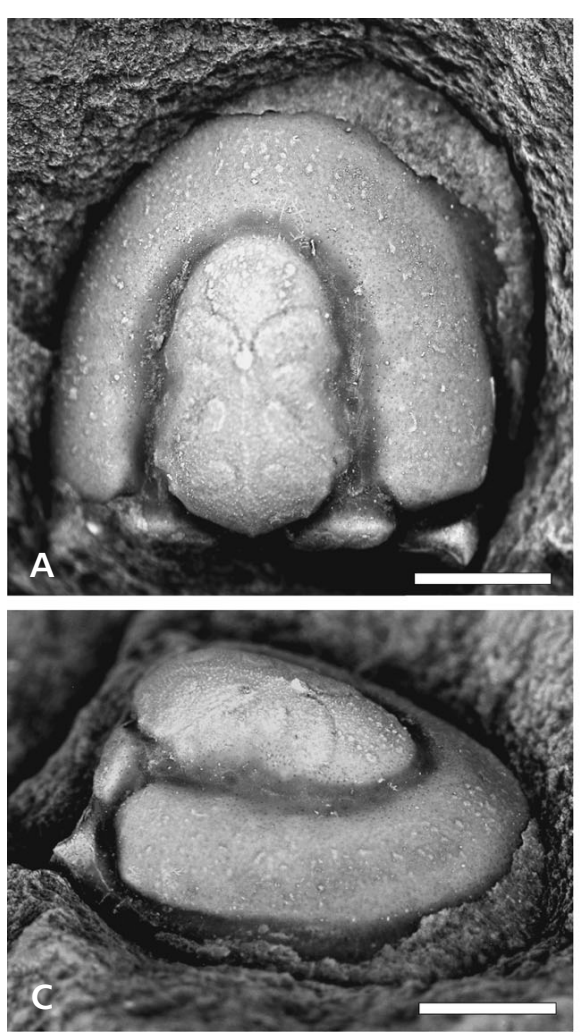
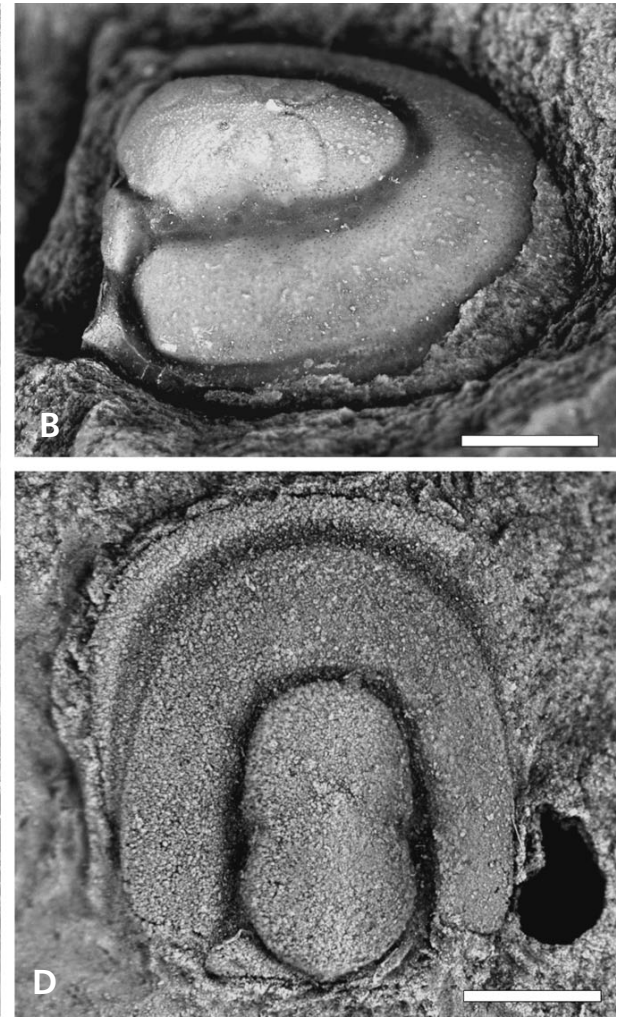

(lectotype and paralectotype) of Arthrorhachis tarda (sensu) Hawle \& Corda (1847), but not as the syntypes of Battus tardus Barrande, 1846.

Material. - Thirty-seven specimens (seven of them complete or almost complete exoskeletons), mostly preserved as external and/or internal moulds in gray and green claystones and siltstones with calcareous admixture, from the lower to upper (but not uppermost) part of the Králův Dvưr Formation. None of the specimens show the malformation described by Fatka et al. (2008).

Diagnosis. - Arthrorhachis with medium-vaulted exoskeleton, narrow cephalic and pygidial border, short posterolateral spines present on cephalon and very short posterolateral spines on pygidium.

Description (after Pek 1977; modified and supplemented). - Cephalon of semi-elliptic outline in dorsal view, moderately vaulted. The glabella (occupying $57-67 \%$ of the total cephalic length) is of elongate ovoid outline, slightly constricted at half of its sag. length. Glabellar node is minute, located approximately in one third of the sag. glabellar length from the anterior glabellar margin. Basal nodes are small, subtriangular, not reaching the vaulting of the glabella. Axial furrows deep and wide. The glabellar muscle insertion areas are very indistinct. In the material coming from the Prague Basin, they are mostly entirely effaced due to poor preservation of the material. Their description is based on the unique, very well preserved specimen C̆GS PK 5, recently collected by the third author of this contribution (see Fig. 4A-C). Anterior glabellar lobe semi-ovate. Anterior transglabellar furrow F3 with very short (tr.) median portion, of equal width as the glabellar node. Lateral portions of F3 curving strongly forward and outward. Dividing transverse furrow indistinct, slightly arched anteriorly, not reaching the axial furrow abaxially. Both F3 and the dividing transverse furrows are located anteriorly of the glabellar constriction. F2 lies posteriorly of this constriction; it is indistinct, almost straight, posteriorly directed, forming an angle of less than $45^{\circ}$ with sag. line. F2 does not meet the lateral margins of the glabella. P6 flat, wide; P5 close to glabellar constriction; P4 minute, indistinct. P2 flat, indistinct, posteriorly limited by narrow, slightly bent furrow. The acrolobe is semi-elliptic in outline and rounded anteriorly. Genae horseshoe-shaped, less vaulted than the glabella, mildly concave at its posterior margin and slightly above the basal lobes. Posterolateral margins of genae protruded into short, blunt spines (Fig. 4A-C). Marginal border narrow, slightly convex, narrowing posteriorly. Marginal furrow broad and deep, reciprocal to the width of the border within its whole length. Rear margin of the cephalon straight.

Thorax of typical Arthrorhachis/Geragnostus type (for other reference, see Ahlberg 1992), with prominent axial rings. Lateral axial lobes large, prominently vaulted and 
rounded. Median lobe keeled, transversally wider than long (sag.). Axial furrows narrow, resembling those dividing the axial ring. Pleurae relatively short (transversal length of pleurae equals tr. length of the axial ring), oriented slightly anteriorly; first pleurae somewhat shorter (tr.) than second pair. Lateral pleural margins bluntly tapering. Pleural furrows slightly widening towards the lateral pleural margin, disappearing about $3 / 4$ of the pleural length. Posterior pleural band moderately vaulted, possibly forming an indistinct lobe on second pleura.

Pygidium of subquadrate outline; its convexity somewhat exceeding the height of the cephalic shield. Pygidial axis constituting one-third of the tr. pygidial width at the anterior margin and about half (it may range between $35-50 \%$ ) of sag. pygidial length. It consists of three different rings (P1-P3); in the sagital axis of the first two lobes, there is a vaulted, prominent median node forming a tubercle or short ridge (see Figs 5E, 6J, K). The lateral parts of $\mathrm{P} 1-\mathrm{P} 2$ are formed by ovoid, medium vaulted lobes, whose longer axes are roughly perpendicular to the axis but widen strongly adaxially, forming deep triangular depressions at merging point with axial furrows. Terminal ring is the narrowest (tr.) and the longest (sag.), moderately vaulted. Its posterior margin is slightly convex. The axial furrows are narrow and deep. Pleural lobes slope evenly towards the outer margins of the pygidium. Border is slightly convex; marginal furrow shallow, wide. Very short, pointed posterolateral spines directed obliquely ventrally. These spines are hardly observable or missing in most of the studied samples (most probably broken off or possibly entirely missing in some specimens). Nevertheless, in some of the best-preserved samples (Fig. 6J), the spines are undoubtedly present. Articulating half-ring narrow (sag.), of the same tr. width as the anterior margin of the pygidial axis. Articulation furrow wide, deepening terminally. Articulating facets narrow, flat, faintly widening exsagitally.

The exoskeletal surface is apparently smooth but in the best-preserved specimens (Fig. 6C-E) finely sculptured with tiny raised lines, often anastomosing lines, forming a polygonal or circular reticulation.

Remarks. - The finding of the well-preserved specimen ČGS PK 5 (Fig. 4A-C) substantially supplemented our knowledge about the cephalic morphology of the species, although already Ahlberg (1989, Fig. 3A) had published a comparatively well-preserved specimen of $A$. tarda (No. LO 5924t) coming from the Jerrestad Mudstone of Scania (Sweden). The shape of the glabellar impressions in both specimens is almost identical (see above). There is only one difference; the dividing transverse furrows are more distinct, straight and longer (even probably fused medially with F3 in the place of its median portion) in the Swedish specimen, where the dividing transverse furrows are deflected anteriorly and they die out both medially and laterally. On the other hand, it is noteworthy, that a very indistinct median keel elevation is developed on posteroglabella in both specimens. The general configuration of the glabellar impressions of $A$. tarda thus really seem to be of typical Arthrorhachis/Geragnostus type - see Fortey (1980, fig. 4A) and discussion in Ahlberg (1989, p. 217). Very similar are also glabellar imprints in Geragnostus hadros Wandås, 1984 figured by Hansen (2009, fig. 63, pl. 26, fig. 13). There exist, however, also notable differences between both species. The glabellar impressions in G. hadros are, above all, more prominent and better developed. The median portion of F3 is relatively wider in G. hadros, its anterolateral part is longer and more arcuate, and the lobes are more vaulted. Despite this, the general shape of these glabellar impressions clearly confirms the close relationship of Geragnostus and Arthrorhachis. The structures observed on specimen ČGS PK 5 are not, however, identical with the four pairs of smooth areas (possible muscle imprints?) known in Galbagnostus galba (see Whittington 1965: pl. 3, fig. 7, 15; pl. 3, fig. 9) and Arthrorhachis latilimbata (Ju in Qiu et al. 1983, cf. Fortey 1997 and Cotton \& Fortey 2005, p. 102, fig. 2F, specimen NHM It 25510). So far, similar structures were not observed in specimens from the Prague Basin.

The length of posterolateral spines on the pygidial border, as well as the degree of anterolateral inclination of the thoracic pleurae in the Barrandian representatives of A. tarda were probably slightly overestimated by Kielan (1960) and also by Pek (1977), correctly interpreted their existence (also Whittington 1950); see reconstruction of Barrande (1852). They are even more rudimentary in Bohemian specimens, compare to Polish and partly the Scandinavian specimens. As noted in the description herein, in nine of thirteen available Bohemian pygidia studied, the

Figure 5. Arthrorhachis tarda (Barrande, 1846). Upper Katian, Králův Dvůr Formation. • A, B - neotype NM L 16534 (older No. ČD 1812), an internal mould (A) of a nearly complete specimen plus counterpart (B), illustrated by Barrande (1852, pl. 49, figs 1, 2) and Pek (1977, pl. 8, fig. 2), Libomyšl (very probably, Lejškov near Libomyšl). The specimen was incorrectly selected as a lectotype by Přibyl (in Horný \& Bastl 1970, p. 308). NM L 16534. - C - damaged incomplete specimen MCZ 112323, Kosov. • D, E - almost entire specimen, NM L NM L 40 8521 (older No. ČD 1813). Marked as a syntype of A. tarda on the label but never published under this designation, questionable specimen AD Barrande (1852, pl. 49, figs 1, 2), Lejškov. $\bullet \mathrm{F}$ - an incomplete specimen, figured by Whittington (1968) on p. 97, MCZ 112325a, Kosov. • G - a cephalon with first thoracic segment, ČGS JV 2494c, figured by Pek (1977) on pl. 8. Figured under the wrong number JV 5294, Králův Dvůr, Ovčín. • H - a damaged entire specimen, ČGS JV $2489 a$, Lejškov. - I - almost entire, 3D preserved specimen, MCZ 112322, figured by Fortey (1997) on pl. 1, fig. 2. Kosov. Scale bar represents 1 mm. 

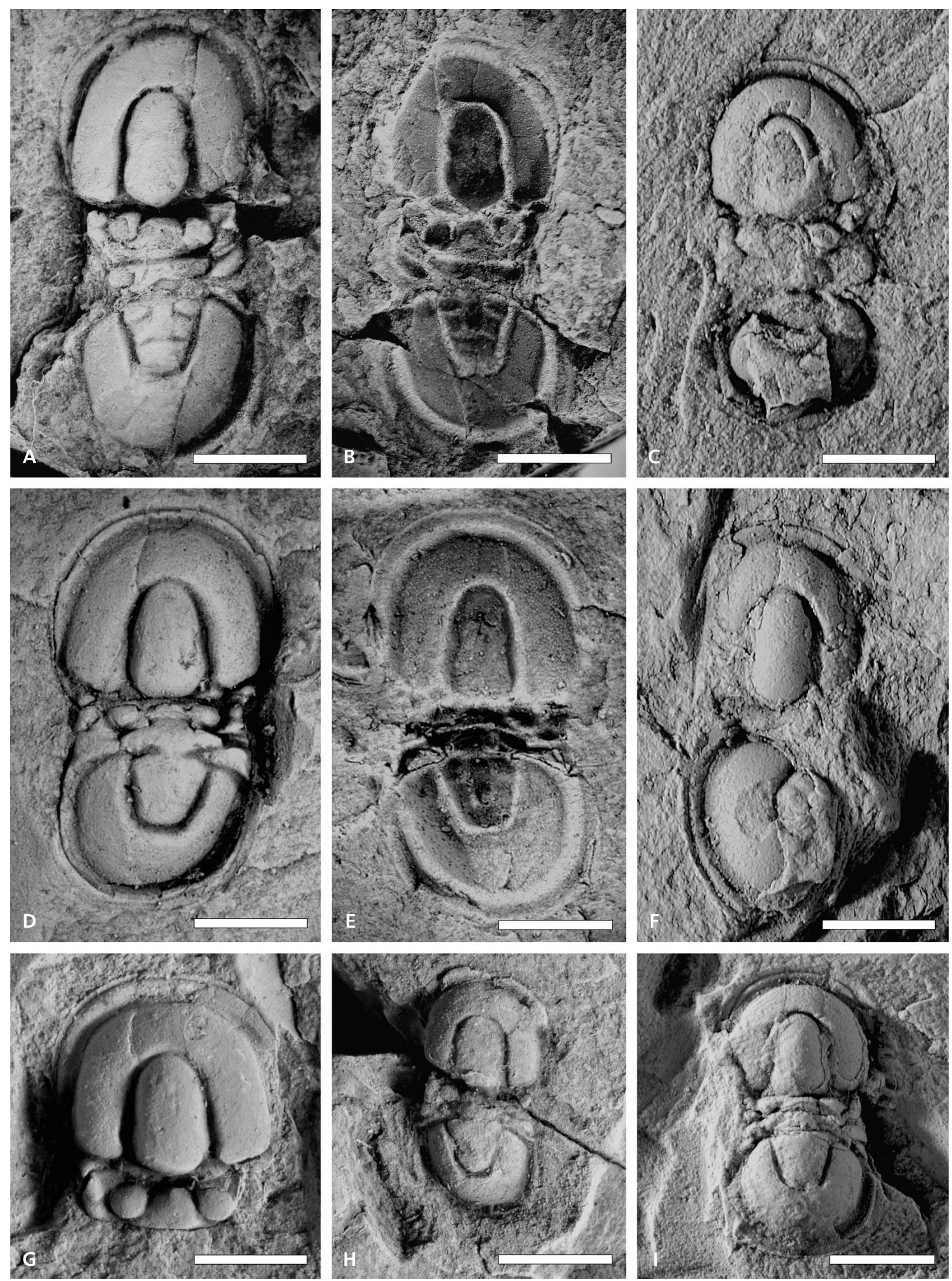
pygidial spines are not seen. Their apparent absence is, however, easily explicable by later diagenesis and/or weathering. At least in some cases the remains of the spine bases are traceable. However, they are hardly perceptible (but present) on the external moulds.

Ontogeny. - One meraspid pygidium of A. tarda from Scania was figured by Ahlberg (1989, Fig. 4I). The newly described cephalon comes from the Barrandian area and is stored in the Scháry collection (Museum of Comparative Zoology, Harvard University under No. MCZ 111324b, Fig. 6F herein). It differs from adult specimens mainly in having relatively longer and narrower glabella, more prominent posterolateral cephalic spines and also by a different width of the cephalic border furrow in the anterior and posterolateral part of the cephalon; these features are comparable with A. elspethi and A. pragensis. The posterior part of the glabella is broken off and it is not entirely excluded that it originally protruded into a short spine. The pygidium LO 5929t, figured by Ahlberg (1989, Fig. 4I) possesses a distinctively longer and more robust pygidial axis ( $50 \%$ of the pygidial length or even more), while the lobes are indistinct.

Variability. - Ahlberg (1989), Hammann \& Leone (1997) and Shaw (2000) emphasized that A. tarda was a highly variable species and rejected the proposal of Morris (1988), to distinguish two species $-A$. tarda and A. convexa (Salter, 1848) on the base of the occurrence of two different morphs: the first one characterized by a long pygidial axis (about $50 \%$ of the pygidial length) which should belong to the A. tarda and a second morph with a shorter axis which should belong to the second species. The variability of these two features in A. tarda is figured here in Fig. 8A. Measurements plotted in this graph agree with the earlier observation of Hammann \& Leone (1997, p. 40), that the length of pygidial axis (43\%) of $A$. convexa falls within the intraspecific variability of $A$. tarda. In the Bohemian material, almost all measurable parameters seem to vary (see also Table 1), especially the relative length of the pygidial axis (average variability 35-50\%, see Fig. 8A), relative length of glabella compared to the cephalic length
(57-67\%). The length of pygidial spines also varies from almost indiscernible to short but present (similar variation in specimens from Bornholm, Denmark, see Ahlberg 1989) but in most cases, the spines may simply be broken. Also the course of the axial furrows on the cephalon varies - they may be almost sub-parallel, to mildly diverging anteriorly. The prominence of pygidial inter-ring furrows is also widely variable. As Ahlberg (1989) noted, the relative glabellar length, for example, might be influenced by differential flattening of the cephalon. It is very hard to distinguish between morphological variability and variation due to different preservation in material from claystone and siltstone localities.

Occurrence in the Barrandian area. - Králův Dvůr Formation (Upper Ordovician, late Katian; Kradvorian Regional Stage), "horizons" with Nankinolithus granulatus and Tretaspis anderssonni (= T. seticornis): Lejškov near Libomyšl (= Leiskow près Malków in Barrande 1852, 1872 and in the Scháry collection, MCZ), Kosov, Králův Dvůr (= Köningshoff in Barrande 1852, 1872), Levín, Karlova Hut near Beroun, Karlík near Dobřichovice, Praha-Radotín and Praha-Velká Chuchle. Disappears beneath the "Perník" Horizon (impure carbonates several meters below the top of the formation).

\section{Arthrorhachis pragensis (Přibyl \& Vaněk, 1968)}

Figures 3B, 4D, 7F-L

1968 Trinodus (Geragnostus) pragensis sp. n.; Přibyl \& Vaněk, p. 191, pl. 1, figs 8, 9.

1977 Trinodus pragensis Přibyl \& Vaněk; Pek, pp. 24, 25, pl. 1, figs 9, 10.

1984 Trinodus pragensis Přibyl \& Vaněk; Pek \& Prokop, pp. 17, 18, pl. 1, fig. 4.

1989 Trinodus pragensis Přibyl \& Vaněk; Pek \& Vaněk, p. 33.

1997 Arthrorhachis pragensis (Přibyl \& Vaněk); Vaněk \& Vokáč, pp. 23, 24, pl. 1, figs 1-5.

2000 Arthrorhachis pragensis (Přibyl \& Vaněk); Shaw, p. 375.

Figure 6. Arthrorhachis tarda (Barrande, 1846). Upper Katian, Králův Dvůr Formation. • A - fragment of cephalon, NM L 5145, coll. Hawle. Lectotype of A. tarda sensu Hawle \& Corda, 1847, as selected by Přibyl in Horný \& Bastl (1970, p. 307). Figured by Šnajdr (1983) on pl. 7, fig. 3. Králův Dvůr. • B - fragment of cephalon, NM L 5144, coll. Hawle, a second syntype of A. tarda sensu Hawle \& Corda, 1847, selected by Přibyl in Horný \& Bastl (1970, p. 307). Králův Dvůr. • C - internal mould of cephalon with part of exoskeleton, NM L 16535 (older No. ČD 1815), syntype of Barrande (AD Barrande 1852, pl. 49, figs 1, 2), selected by Přibyl in Horný \& Bastl (1970, p. 308), Králův Dvůr. • D - internal mould of cephalon with remains of the exoskeleton, ČGS XB 177 (coll. ČVUT), Králův Dvůr. • E - internal mould of damaged cephalon with remain of the first thoracic segment, MCZ 112324a, Köningshoff (= Králův Dvůr) • F - a juvenile (meraspid) cephalon, MCZ 112324b, Köningshoff (= Králův Dvůr). • G - internal mould of cephalon and a negative counterpart of a second cephalon with debris of other minute fauna, MCZ 112324c, Köningshoff (= Králův Dvůr). $\bullet H$-internal mould of damaged cephalon, NM L 40853, Köningshoff (= Králův Dvůr) • I - internal mould of damaged pygidium, MCZ 114040, Králův Dvůr. • J - internal mould of incomplete pygidium, MCZ 112325b, Králův Dvůr. $\bullet$ K - internal mould of incomplete pygidium, ČGS JV 2494a, Lejškov. • L - internal mould of incomplete pygidium, NM L 40 854, Králův Dvůr. Scale bar represents 1 mm. 

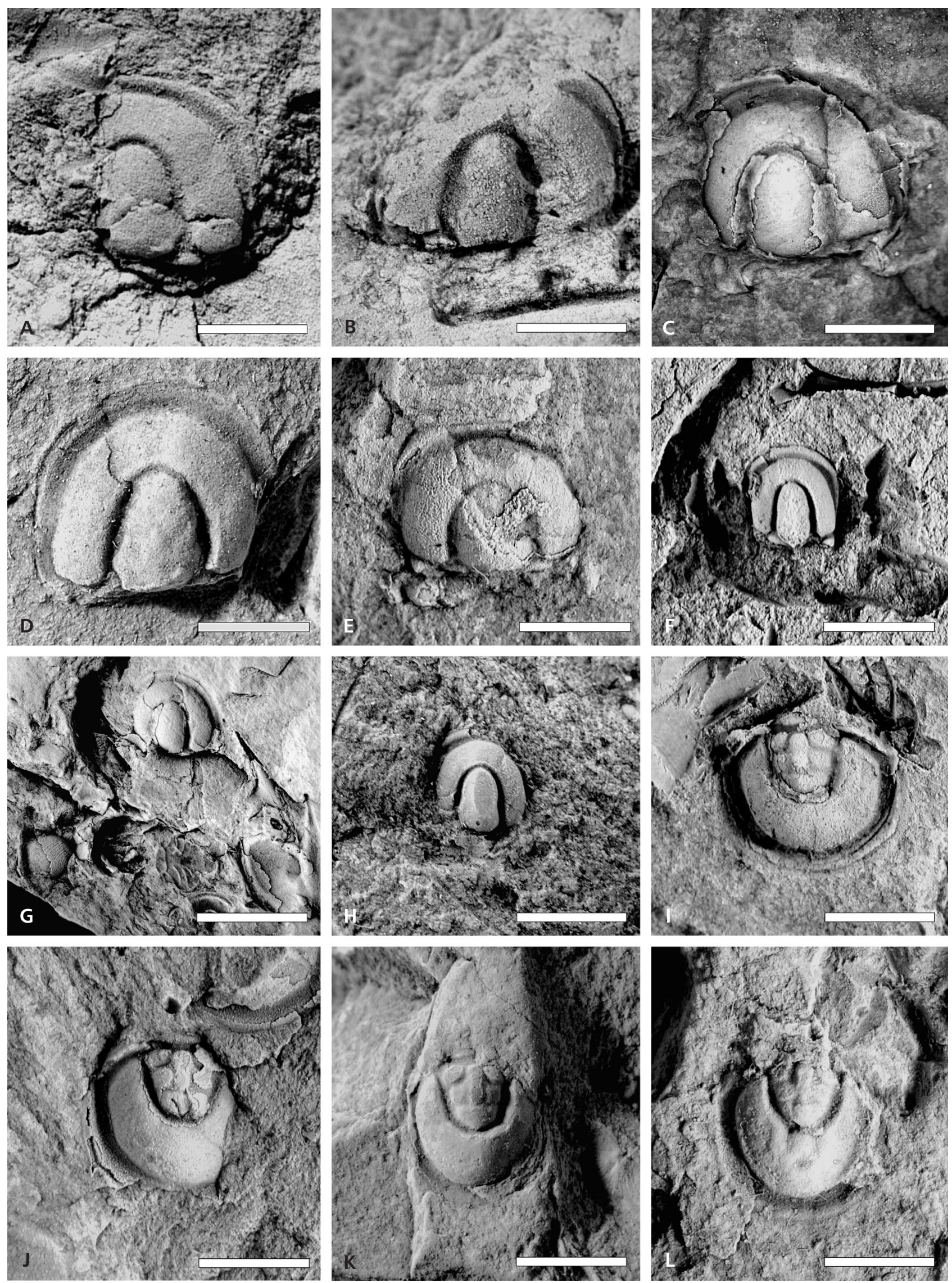
2001 Arthrorhachis pragensis (Přibyl \& Vaněk). - Vaněk \& Valíček, p. 43.

Holotype. - Isolated pygidium figured by Přibyl \& Vaněk (1968; pl. I, fig. 9; ČGS JV 6), re-figured by Pek (1977; pl. I, fig. 10) and Vaněk \& Vokáč (1997; pl. I, fig. 5), herein Fig. 7G. The external mould of this pygidium, firstly figured herein in Fig. 7H, stored in the collections of the Czech Geological Survey, under No. ČGS JV 2501.

Dimensions in $\mathrm{mm}: \mathrm{Lp}=3.1 ; \mathrm{La}=1.4 ; \mathrm{Wp}=3.2$; $\mathrm{Wa}=1.1 ; \mathrm{Ls}=1.0$. These measurements differ slightly from those of Pek (1977), probably due to better equipment in the form of digital micrometric ruler used for this study.

Type locality and horizon. - Praha-Hloubětín, abandoned brickyard "Na bílém koni”, Bohdalec Formation, Karlík ore Horizon (Lower Katian Stage, Late Berounian Regional Stage) Upper Ordovician, Prague Basin, Barrandian area, Czech Republic.

Material. - Eleven specimens (seven cephala and four pygidia) preserved as internal moulds and counterparts in dark grey claystones; one specimen (Fig. 4D) originates from a siliceous nodule.

Diagnosis. - Arthrorhachis with exoskeleton of low-convexity and broad anterior border furrow (clearly broadest in its anterolateral part). Cephalic axial furrows almost sub-parallel. No or very indistinct spines at the genal angles; pygidium with short but stout, backwardly directed posterolateral spines.

Description (see Vaněk \& Vokáč 1997; modified). - Cephalon is moderately convex, subquadratic in outline, subequal in length and width, with the highest point at the median glabellar node. The glabella, occupying 55-60\% of the total cephalic length, is moderately convex, nearly parallel-sided to gently forward tapering; broadly rounded anteriorly and well defined by deep axial furrows. It is 2.1 times as long as wide and faintly constricted behind to the mid-length. Posterior part of the glabella is slightly narrower than the anterior part. The glabellar median node is relatively prominent, sagittally elongated and situated slightly anterior to the glabellar midpoint. The glabellar muscle insertion areas are indistinct. The anterior pair of the lateral glabellar imprints is very short, placed at the glabellar constriction. The basal lobes are subtriangular, wider than long, and connected medially. The basal furrows are distinct. The acrolobe is semi-elliptic in outline and rounded anteriorly. Genae horseshoe-shaped with maximum convexity in the mid of length (tr.), slope downwards, narrowing anteriorly. Genal surface possibly smooth. Marginal border relatively narrow, separated from the inner cephalic region by deep furrow.

The border is relatively narrow, lath-like convex and reaches maximum convexity and transversal width along the anterolateral margins. Border furrow distinctly wider (ca 3 times) in the anterolateral part of the cephalon. The genal angles without or with very indistinct spines.

Thorax unknown.

Pygidium subpentagonal in outline. Pygidial axis vaulted, reaching half (45-50\%) the length (sag.) of the pygidium, and about one third its width (tr.) at the anterior margin. It is divided into three rings by conspicuous furrows. A keeled median node rises posteriorly and lies in the sag. length of the first two segments. The terminal ring is longest, posteriorly markedly rounded and slightly bulbous. The axial furrows are narrow and well-defined. The border is relatively broad, broadest in its posterolateral portion, where it sends out a pair of short, stout spines directed backwards. The pleural field is probably smooth, wider posteriorly than laterally.

Discussion. - A. pragensis differs from A. tarda in (1) having distinct and stout posterolateral spines with robust bases, (2) shallower pygidial border furrow, (3) narrower cephalic border, (4) slightly more (sag.) elongated cephalon

Figure 7. A-C - Arthrorhachis tarda (Barrande, 1846). Upper Katian, Králův Dvůr Formation. • A - internal mould of incomplete cephalon with remains of exoskeleton, ČGS PB 500, Lejškov. • B - internal mould of incomplete pygidium, ČGS JV 2494b, Králův Dvůr, Ovčín. • C - internal mould of incomplete pygidium with long axis, JV 2493d, Lejškov. • D - Arthrorhachis cf. tarda (Barrande, 1846), MCZ 114035. Upper Katian?, Rhiwlas Limestone, Craig y Gath, Wales. • E - Arthrorhachis elspethi (Raymond, 1925), MCZ 100954. Katian?, Athen Shale, Tennessee, Hawkins, Ina railroad cutting, S of Otes, N of Bulls Gap, USA. Figured by Raymond (1925) on pl. 1, fig. 4. • F-L-Arthrorhachis pragensis (Přibyl \& Vaněk, 1968). Lower Katian, Bohdalec Formation. • F - an incomplete cephalon, NM L 20022, figured by Pek \& Prokop (1984) on pl. 1, fig. 3, Praha-Žižkov, upper part of Bohdalec Formation. • G - isolated pygidium (internal mould), holotype, figured by Přibyl \& Vaněk (1968) on pl. I, fig. 9 (ČGS JV 6), figured by Pek (1977) on pl. I, fig. 10 and Vaněk \& Vokáč (1997) on the pl. I, fig. 5; brickyard "Na bílém koni”, Karlík ore Horizon, basal part of the Bohdalec Formation. • H - counterpart of the same specimen, stored in the collections of the Czech Geological Survey under No. C̆GS JV 2501.・I - a damaged cephalon figured by Pek (1977) on pl. 1, fig. 9, ČGS JV 2502, Vysočany, building pit of the "Health Centre Vysočany". • J - internal mould of almost complete cephalon, ČGS MŠ 11545a, building exposure of the underground line A, area between Praha-Kačerov and Praha-Spořilov (upper part of Bohdalec Formation). $\bullet \mathrm{K}$ - internal mould of incomplete cephalon, ČGS MŠ 115545b, building exposure of the underground line A, area between Praha-Kačerov and Praha-Spořilov (upper part of the Bohdalec Formation). $\bullet$ L-incomplete pygidium, ČGS MŠ 11545b, building exposure of the underground line A, area between Praha-Kačerov and Praha-Spořilov (upper part of the Bohdalec Formation). Scale bar represents $1 \mathrm{~mm}$. 
Petr Budil et al. - Agnostide Arthrorhachis in the Prague Basin
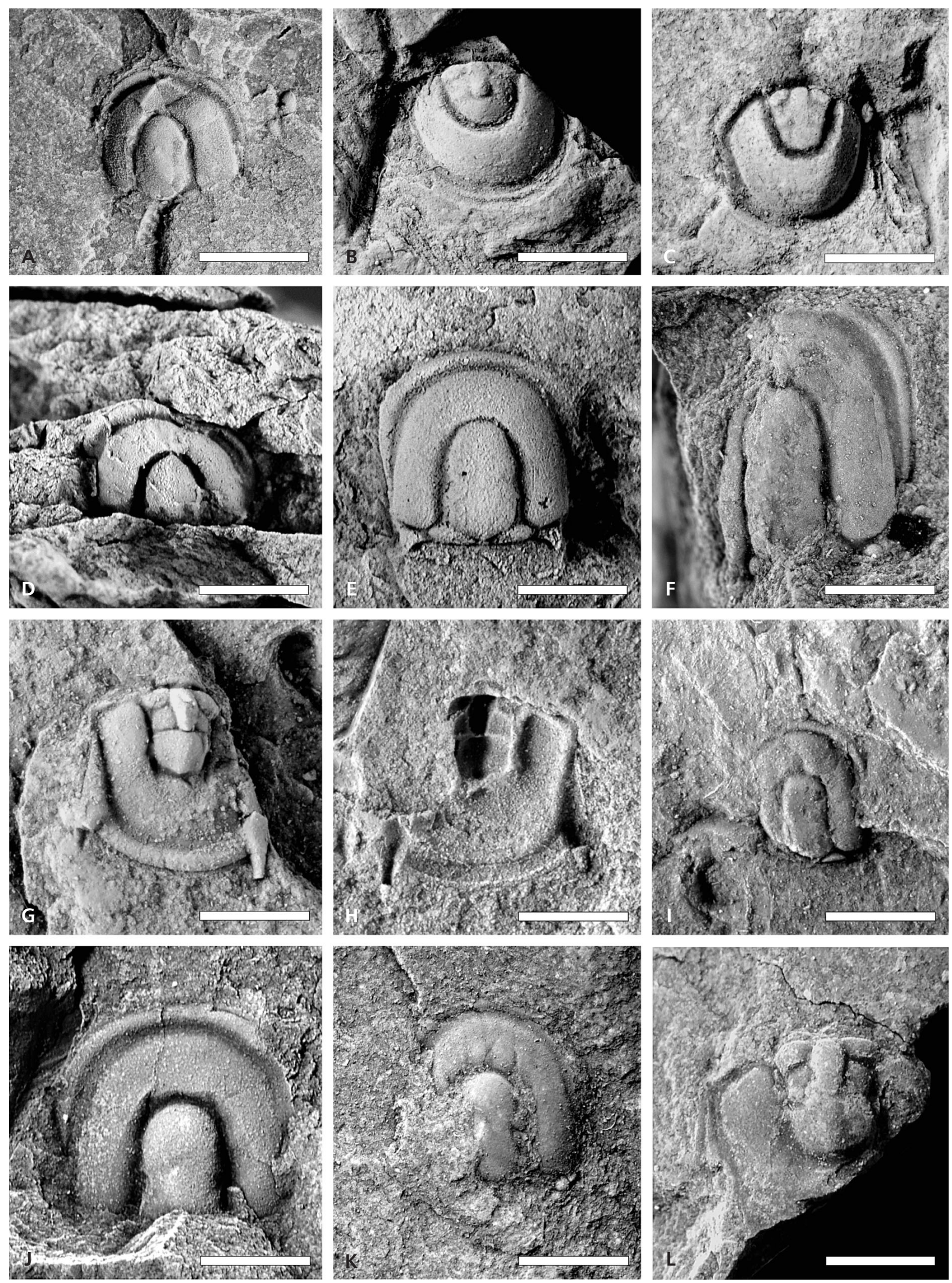

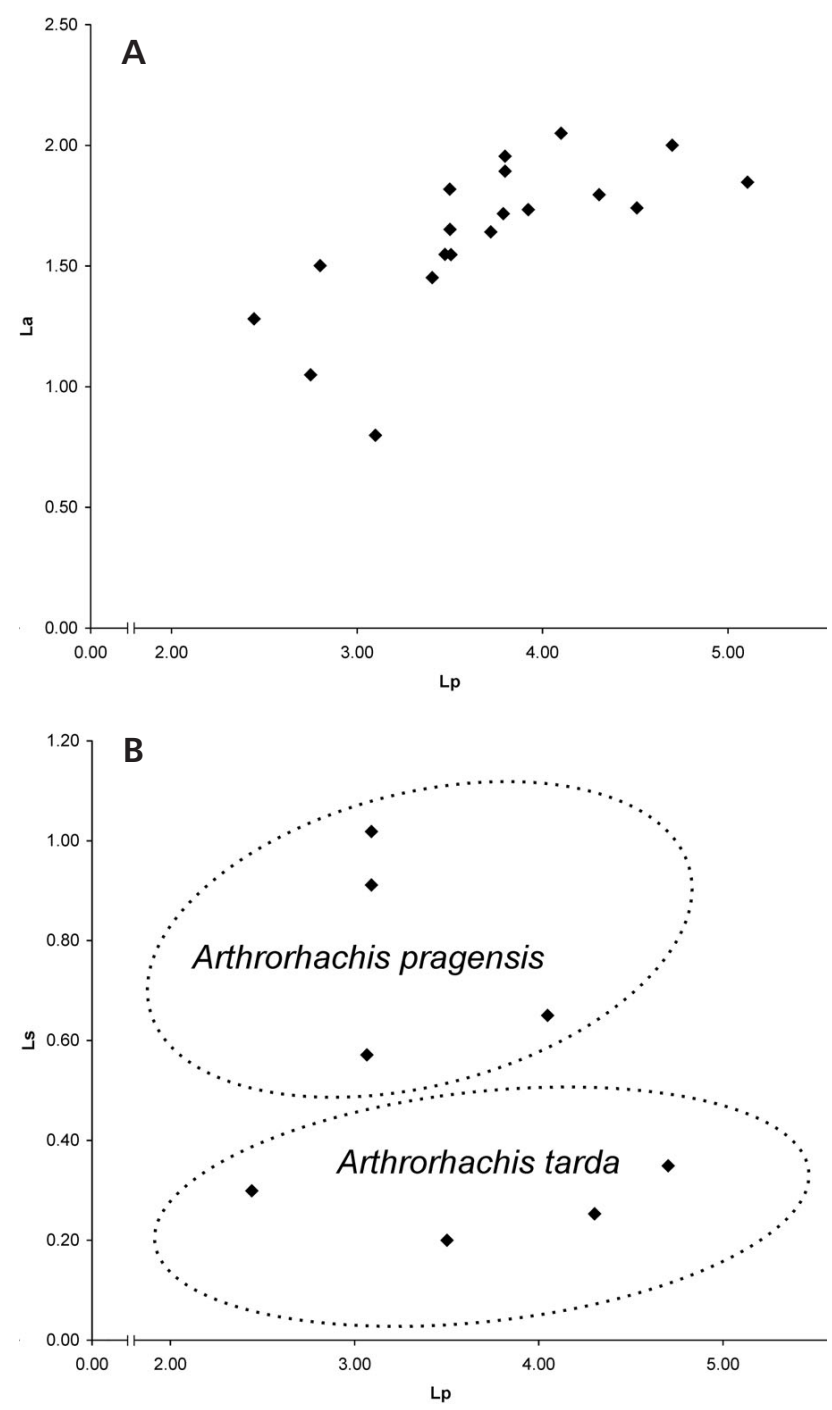

Figure 8. A - a graph of the $\mathrm{Lp} / \mathrm{La}$ ratio in Arthrorhachis tarda. - B - a graph of Lp/Ls ratio in Arthrorhachis tarda and in Arthrorhachis pragensis.

of more rectangular outline, and (5) possibly also by lower convexity of the pygidial pleural field. In A. pragensis, the cephalic border furrow is prominently wider in its anterior part than posterolaterally (up to 3 times) and the cephalic border is somewhat narrower. Basal glabellar lobes are tr. long and wider than in A. tarda, and in contact with the glabellar axis. The pygidium of A. pragensis shows a comparatively longer pygidial axis with slightly bulbous P3. Shaw (2000) noted that these differences are probably too small and did not exclude conspecifity of the species. On the other hand, Nielsen (1997) affiliated A. pragensis to his elspethi group within Arthrorhachis. To test the validity of $A$. pragensis, we compared the relative (sag.) length of posterolateral pygidial spines (Ls) with the sag. pygidial length (Lp) in both species (Fig. 8B). A. tarda and $A$. pragensis form two distinctive clusters; one intermediate pygidium of $A$. pragensis shows a position close to the A. tarda representatives. This specimen, ČGS JV 2498, is a poorly preserved fragment and it could not be excluded that the ends of spines are broken off. However, this specimen also has robust, keel-like bases of the spines, which are oriented almost posteriorly (narrow base and posterolateral inclination present in A. tarda). From A. elspethi, A. pragensis differs especially in the strongly reduced, almost indistinct posterolateral cephalic spines ( $c f$. Fig. 7E). Hence we consider A. pragensis a well-based species which, although probably closely related to A. tarda (possible ancestor) is fully sustainable as a separate species.

Occurrence. - Upper Ordovician, Upper Sandbian Stage, upper part of the Zahořany Formation: temporary exposure of the "Vysočany health centre" (facies of dark-grey claystones), Libomyšl (exact stratigraphical level unknown). Upper Ordovician, lower Katian Stage, Bohdalec Formation (occurring in all levels of a dark shale sequence): Praha-Hloubětín, abandoned brickyard "Na bílém koni" (also in "Karlík ore Horizon" at the base of the formation), Praha-Žižkov (upper part of the Bohdalec Formation), the building exposure of the underground line $\mathrm{A}$ in the area between Praha-Kačerov and Praha-Spořilov (upper part of the Bohdalec Formation), Nová Dubeč (loose siliceous nodule found in the field exposure after Pek \& Prokop 1984), Reporyje, abandoned brickyard "Reiserova cihelna", area between Neumětely and Lážovice (material comes from drilling cores, see Vaněk \& Vokáč 1997), Neumětely temporary pits.

\section{Relation of $A$. tarda and $A$. pragensis to other occurrences}

The almost cosmopolitan occurrence of $A$. tarda and allied species within the former Rheic Ocean has been widely discussed, especially by Ahlberg (1989), Nielsen (1997, 1999), Hammann \& Leone (1997) and Shaw (2000). There is a little to add to these compilations, with the exception of its palaeogeographic distribution (Fig. 9).

However, there is still a little doubt whether all the specimens of $A$. tarda and the forms designated as $A$. aff. tarda and $A$. cf. tarda are really identical with the type material. Some morphological features show a comparable variability (glabellar and especially pygidial axis relative length ratio, pygidial axis outline, length/width ratio of the cephalon and pygidium) in all forms. We agree with Ahlberg (1989), Hammann \& Leone (1997), Shaw (2000) and Owen \& Parkes (2000), that diverse intensity of flattening and orientation of tectonic deformation could be responsible for major part of the alleged variability, especially in specimens preserved in claystones and siltstones. 
The Scandinavian, Polish and some Irish material (Owen \& Romano 2010; Grangegeeth Terrane) is identical with $A$. tarda. Similarly, we suppose the specimens from Kazakhstan are conspecific with A. tarda (see Apollonov 1974). The differences in the relative glabellar and pygidial length between Bohemian and those from the British Isles determined as A. tarda (Ingham 1970, Dean 1971 and Whittington 1968) were probably caused by different preservation, as discussed earlier by Ahlberg (1989). We also agree with Ahlberg (1989), that the specimen of Owen (1981, pl. 1, figs 1-3) probably belongs to A. tarda, similarly as the specimen of Abdullaev (1972), while the specimen of Owen \& Bruton (1980, pl. 1, figs 1-4) probably represents a different species. All other occurrences of A. tarda should be considered as questionable, belonging to the A. tarda species group s.s.

On the other hand, we are not sure about the congeneriic status, let alone conspecificity, of Arthrorhachis tarda and Trinodus agnostiformis as noted above. Therefore, we follow the Fortey's (1980) proposal to restrict the genus Trinodus to the holotype of the T. agnostiformis.

\section{Remarks on the stratigraphy of the Králův Dvưr Formation}

After Shaw (2000), A. tarda has been considered as a typical member of the "Tretaspis granulatus" Zone belonging to the lower part of the Králův Dvůr Formation. Shaw (2000) also pointed out that in the Scháry collection (the second largest collection of the Bohemian trilobites assembled during the $19^{\text {th }}$ century and now stored in the Museum of Comparative Zoology, Harvard University, USA), there are several specimens of $A$. tarda, probably originating from younger part of the Králův Dvůr Formation (e.g. the Kosov locality). This information is correct. A similar wide stratigraphical range of $A$. tarda was already proposed by Havlíček \& Vaněk (1966, pp. 40, 41) and by Pek (1977, p. 26). These authors discussed two diverse levels with A. tarda; the Tretaspis granulatus and Tretaspis seticornis horizons sensu Havlíček \& Vaněk (1966), see also Ahlberg (1989) and Whittington et al. (1997). In fact, there is a serious doubt whether all the material collected from the classical "Tretaspis granulatus" Zone (with type locality called Leiskow or Lejškov) comes from the lower part of the Králův Dvưr Formation. In the period 2009-2010, the authors did an excavation and collected in the place, which has been traditionally supposed to be Barrande's Lejškov locality. The outcrop was originally identified as Barrande's locality by Marek (1961, p. 38), and the fauna was published by Havlíček \& Vaněk (1966, p. 40), while its location was pointed out by Havlíček (in Chlupáč et al. 1987, p. 17) with a reference to Bouček (1928). Meanwhile, doubts based on the personal consultation with Marek and Chlupáč about

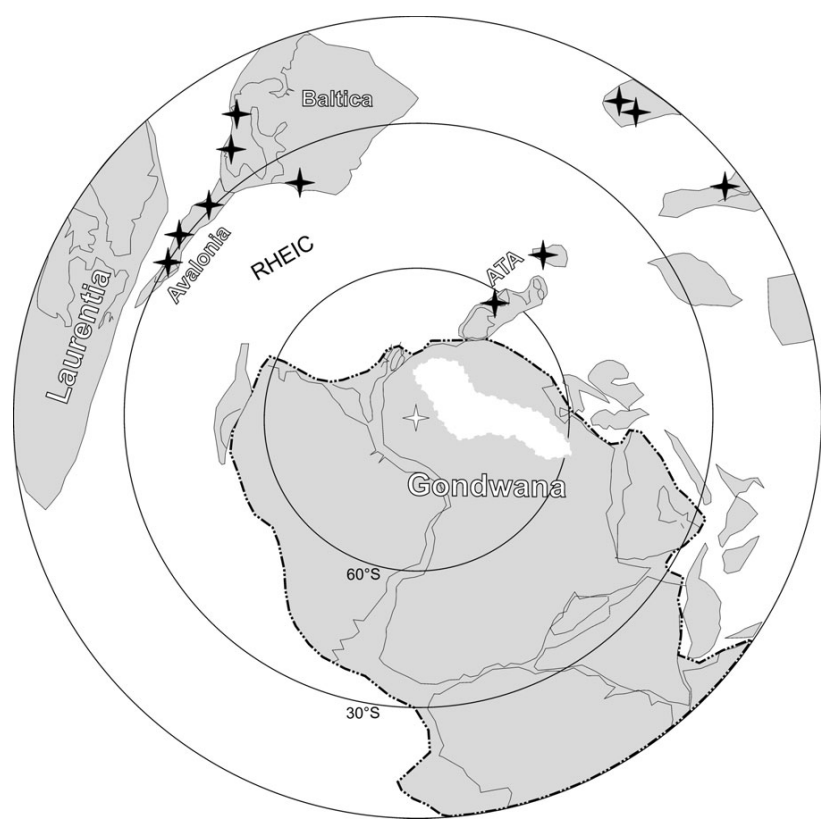

Figure 9. A palaeogeographical occurrence of the Arthrorhachis tarda (Barrande, 1846) and closely related species (A.tarda s.s.). The figured occurrences were compiled from these publications: 1) European peri-Gondwana, ATA (Armorican Terrane Assemblage): Bohemia (Barrande 1846, 1852; Hawle \& Corda 1847; Pek 1977; Fatka \& Pek 1999), Italy (Leone et al. 2001); 2) Avalonia: South Wales (Dean 1971), North Wales (Whittington 1968), Northern England (Ingham 1970); 3) Baltica: Norway (Owen \& Bruton 1980, Ahlberg 1989), Sweden (Ahlberg 1989), Denmark (Ahlberg 1989), Poland (Kielan 1960, Tomczykowa et al. 1972); 4) Kazakhstania: Kazakhstan (Apollonov 1974), Uzbekistan (Abdullaev 1972); 5) Northern China (Zhou \& Dean 1986, Zhou 1987). Map adapted after Fatka \& Mergl (2009) and the discussion by Kř́íž \& Steinová (2009).

this location were expressed by Shaw (2000, p. 392) and Chlupáč (2002, Table 2). The locality discussed is situated in the wooden gorge with steep walls and a small brook above the Lejškov village, about $1 \mathrm{~km} \mathrm{SW}$ of Málkov. In the bottom of the brook, the dark grey to greenish shale containing the characteristic fauna of the "Lejškov Facies" (including A. tarda, see Fig. 7A) occurs, but typical dark grey claystone is only locally developed. At the outcrop, traces of strong tectonism - larger and smaller faults as well as intensive folding and up to $0.5 \mathrm{~m}$ thick cataclastic zones obscure the section.

It is likely, that the association designated as coming from the Lejškov locality (based on existing old collections) actually includes material gathered from a much wider stratigraphical interval than has been supposed.

It could come from the lowermost to middle levels of the Králův Dvůr Formation. This interpretation is supported by a highly variable color of the fossiliferous claystones, stored under the name Lejškov or Leiskow in the old collections. Similarly variable rock types are present at the outcrop. This interpretation is supported by the finding of Nankinolithus granulatus, the "index" trilobite 
species of the lower part of the Králův Dvůr Formation, associated with graptolites typical for the middle to upper part of the formation (see Havlíček \& Vaněk 1990, Havlíček \& Fatka 1992, Havlíček 1998), namely Normalograptus angustus (Perner) and Dicellograptus cf. laticeps Štorch (determination by P. Štorch) on one rock slab.

There is no known occurrence of $A$. tarda in the "Perník Horizon", a richly fossiliferous bed of impure bioclastic carbonate developed usually a few meters below the top of Králův Dvůr Formation and overlying strata in the Prague Basin. On the other hand, Kielan (1960) reported the species in several sections in the Holy Cross Mountains of Poland, from strata yielding among others Mucronaspis mucronata, Brongniartella platynota, Leonaspis olini, and Phillipsinella parabola. These strata, designated as the Dalmanitina Beds by Kielan (1960), have been considered to be of Hirnantian age ( $c f$. Owen 1986, table 2). Ahlberg (1989) did not support this stratigraphic correlation. He argues, that $M$. mucronata and several of the associated trilobites appear already in the Jerrestadian Stage in Sweden; thus it could be difficult to distinguish between the lower Dalmanitina Beds and the Staurocephalus clavifrons Zone of the upper Jerrestadian Stage. In Baltica, the FAD of Mucronaspis is thus already in the late Katian (Ahlberg 1989). In the Barrandian area, such a co-occurrence of Arthrorhachis and Mucronaspis has not been proved. The last specimens of Arthrorhachis disappear below the first appearance of Mucronaspis in the "Perník Horizon" in this area. Recently, Mergl (2011) documented the occurrence of the first Hirnantian brachiopods from the "Perník Horizon" at the Reporyje locality.

\section{Acknowledgements}

This contribution benefited from the helpful improvement of the English and constructive suggestions made by R.A. Fortey and from the critical review that very improved this manuscript made by T. Hansen. We would like to express many thanks to the staff of the Palaeontological department of the National Museum, Prague, namely to V. Turek, M. Valent and J. Cundiff (Museum of Comparative Zoology, Harvard University, Boston, U.S.A.) for their generous help with tracing and photographing the specimens, far beyond their curatorial responsibilities. The study was supported by grants from the Ministry of Education (Project No. MSM0021620855) and the Grant Agency of Czech Academy of Science through the Project No. IAA301110908.

\section{References}

ABDULlaEv, R.N. 1972. Trilobity verkhnego ordovika Bukantau [Upper Ordovician trilobites of Bukantau], 103-126. In MASUmov, A.S. \& Abdulaev, R.N. (eds) Novye dannye po faune paleozoya $i$ mezozoya Uzbekistana. Akademiya Nauk Uzbekskoy SSR, Institut Geologii i Geofiziki, Tashkent.

Ahlberg, P. 1989. Agnostid trilobites from the Upper Ordovician of Sweden and Bornholm, Denmark. Bulletin of the Geological Society of Denmark 37, 213-226.

AhlBerg, P. 1992. Agnostid trilobites from the Lower Ordovician of Sweden. Transactions of the Royal Society of Edinburgh, Earth Sciences 83, 539-570.

Angelin, N.P. 1851. Palaeontologia Svecica. I: Iconographia Crustaceorum formationis transitionis. Fascicule 1. 24 pp. Lund.

Apollonov, M.K. 1974. Ashgillskie trilobity Kazakhstana. [Ashgillian trilobites of Kazakhstan.] 136 pp. Akadyemiya Nauk Kazakhskoi SSR, Institut Geologicheskikh Nauk, Alma-Ata. [in Russian]

BARRANDE, J. 1846. Notice préliminaire sur le Système Silurien et les trilobites de Bohême. 97 pp. Leipzig.

BARRANDE, J. 1852. Système silurien du centre de la Bohême. Volume I. 935 pp. Privately published, Prague \& Paris.

BARRANDE, J. 1856. Bemerkungen über einige neue Fossilien aus der Umgebung von Rokitzan im silurischen Becken von Mittel-Böhmen. Jahrbuch der Kaiserlich-königlichen geologischen Reichsanstalt 2(355), 1-6.

BARRANDE, J. 1872. Système silurien du centre de la Bohême. Volume I, Supplement I. 647 pp. Privately published, Prague \& Paris.

BouČEK, B. 1928. O vrstvách zahořanských $-\mathrm{d}_{\varepsilon}$ českého ordoviku. Rozpravy České akademie věd a umění, Tř́da II 37, 1-33.

Bruton, D.L. \& NAKREM, H.A. 2005. Enrolment in a Middle Ordovician agnostoid trilobite. Acta Palaeontologica Polonica 50(3), 441-448.

Bruton, D.L. \& Owen, A.W. 1979. Late Caradoc-early Ashgill trilobite distribution in the central Oslo Region, Norway. Norsk Geologisk Tidsskrift 59, 213-222.

CHLupÁč, I. 2002. Explanatory remarks to reprinted Joachim Barrande: Système silurien du centre de la Bohême. Vol. 1. Crustacés: Trilobites. 47 pp. Trilobit (published by Petr Materna), Praha.

Chlupáč, I., Brunnerová, Z., Havlíček, V., Kovanda, J., KŘíž, J., ŠAlANSKÝ, K., S̆TYCh, J. \& ZelenKa, P. 1987. Vysvětlivky k základní geologické mapě 1 : 25 000, 12-413 Králův Dvưr. 108 pp. Ústřední ústav geologický, Praha.

Cotton, T.J. \& Fortey, R.A. 2005. Comparative morphology and relationships of the Agnostida, 95-136. In Koenemann, S. \& JenNer, R. (eds) Crustacean Issues 16, Crustacea and Arthropod Relationships. CRC Press, Boca Raton. DOI 10.1201/9781420037548.ch5

Dean, W.T. 1971. The trilobites of the Chair of Kildare Limestone (Upper Ordovician) of eastern Ireland 1. Palaeontographical Society (Monograph) 125, 1-60.

FatKa, O. \& Mergl, M. 2009. The "microcontinent" Perunica: status and story 15 years after conception, 65-102. In BASSETT, M.G. (ed.) Early Palaeozoic Peri-Gondwanan Terranes: New Insights from Tectonics and Biogeography. The Geological Society of London, Special Publications 325.

Fatka, O., Szabad, M. \& Budil, P. 2009. Malformed agnostids from the Middle Cambrian Jince Formation of the Př́bramJince Basin. Bulletin of Geosciences 84(1), 121-126. DOI 10.3140/bull.geosci.1107 
FatKa, O. \& Pek, I. 1999. Ordovician agnostid trilobites of the Prague Basin (Barrandian area, Czech Republic), 381-384. In Kraft, P. \& Fatka, O. (eds) Quo vadis Ordovician? Acta Universitatis Carolinae, Geologica 43(1-2).

ForTEY, R.A. 1980. The Ordovician trilobites of Spitsbergen. III. Remaining trilobites of the Valhallfonna Formation. Norsk Polarinstitut Skrifter 171, 1-163.

Fortey, R.A. 1997. Late Ordovician trilobites from Southern Thailand. Palaeontology 40(2), 397-449.

Fortey, R.A. \& Owens, R.M. 1987. The Arenig series in South Wales: Stratigraphy and Palaeontology. Bulletin of the British Museum (Natural History), Geology 41(3), 169-307.

Hammann, W. \& Leone, F. 1997. Trilobites of the post-Sardic (Upper Ordovician) sequence of southern Sardinia. Part 1. Beringeria 20, 1-217.

Hansen, T. 2009. Trilobites of the Middle Ordovician Elnes Formation of the Oslo Region, Norway. Fossils and Strata 56, $1-215$.

Havlíček, V. 1998. Ordovician, 149-164. In Chlupáč, I., HavLİ̌̌EK, V., KŘižz̆, J., KuKAL, Z. \& ŠTORCh, P. (eds) Paleozoic of the Barrandian (Cambrian to Devonian). Czech Geological Survey, Prague.

HavlíčEK, V. \& FatKa, O. 1992. Ordovician of the Prague Basin (Barrandian area, Czechoslovakia), 461-472. In WeBBy, B. \& LAURIE, J. (eds) Global perspectives on Ordovician geology. Balkema, Rotterdam.

HAVLÍČEK, V. \& VANĚK, J. 1966. The Biostratigraphy of the Ordovician of Bohemia. Sborník geologických věd, Paleontologie 8, 7-69.

HAVLÍČEK, V. \& VANĚK, J. 1990. Ordovician invertebrate communities in black-shale lithofacies (Prague basin, Czechoslovakia). Věstník Ústředního ústavu geologického 65(4), 223-236.

Harper, J.C. 1952. The Ordovician rocks between Collon (Co. Louth) and Grangegeeth (Co. Meath). Scientific Proceedings of the Royal Dublin Society, New Series 26, 85-112.

Hawle, J. \& CoRda, A.J.C. 1847. Prodrom einer Monographie der bohmischen Trilobiten. 176 pp. J.G. Calve, Prague.

HornÝ, R. \& BASTL, F. 1970. Type specimens of fossils in the National Museum Prague, I. Trilobita. 356 pp. Museum of Natural History, Praha.

InGHAM, J.K. 1966. The Ordovician rocks in the Cautley and Dent districts of Westmorland and Yorkshire. Proceedings of the Yorkshire Geological Society 35, 455-505. DOI 10.1144/pygs.35.4.455

InGHAM, J.K. 1970. The Upper Ordovician trilobites from the Cautley and Dent districts of Westmorland and Yorkshire 1. Palaeontographical Society (Monograph) 124, 1-58.

JAEKEL, O. 1909. Ueber die Agnostiden. Zeitschrift der Deutschen geologischen Gesellschaft 61, 380-401.

JELL, P.A. \& Adrain, J.M. 2002. Available generic names for trilobites. Memoirs of the Queensland Museum 48(2), 331-553.

KiELAN, Z. 1956. Stratygrafia górnego ordowiku w Górach Swietokrzyskich (On the stratigraphy of the Upper Ordovician in the Holy Cross Mts.). Acta Geologica Polonica 6(3), 253-271. [in Polish with English summary]

Kielan, Z. 1960. Upper Ordovician trilobites from Poland and some related forms from Bohemia and Scandinavia. Palaeontologica Polonica 11, 1-198.
KŘiž, J. \& SteinovÁ, M. 2009. Uppermost Ordovician bivalves from the Prague Basin (Hirnantian, Perunica, Bohemia). Bulletin of Geosciences 84(3), 409-436.

DOI 10.3140/bull.geosci.1141

Kobayashi, T. 1935. The Cambro-Ordovician formations and faunas of South Chosen. Palaeontology of the Faculty of Science, Imperial University of Tokyo (section II) 4, 49-344.

Koliha, J. 1922. Příspěvek ku poznání rodu Agnostus [Contribution to the knowledge on the genus Agnostus]. Věda přirodní A III, 1-6. [in Czech.]

Koroleva, M.N. 1982. Trilobity ordovika severo-vostochnogo Kazakhstana [Ordovician trilobites of Northeast Kazakhstan]. 192 pp. Nedra, Moskva.

Leone, F., Hammann, W., Laske, R., Serpagli, E. \& Villas, E. 1991. Lithostratigraphic units and biostratigraphy of the postSardic Ordovician sequence in south-west Sardinia. Bolletino della Società paleontologica Italiana 30(2), 201-235.

MareK, J. 1961. The Trilobite Family Cyclopygidae Raymond in the Ordovician of Bohemia. Rozpravy Ústředního ústavu geologického 28, 1-84.

Mergl, M. 2011. Earliest occurrence of the Hirnantia Fauna in the Prague Basin (Czech Republic). Bulletin of Geosciences 86(1), 63-70. DOI 10.3140/bull.geosci.1245

M'Coy, F. 1846. A synopsis of the Silurian fossils of Ireland. 72 pp. Dublin University Press, Dublin.

M'Coy, F. In Sedgwick, A. \& M'Coy, F. 1851-1855. A synopsis of the classification of the British Palaeozoic rocks, with a systematic description of the British Palaeozoic fossils in the geological museum of the University of Cambridge. 1851, Fasc. I, 1-184; 1852, fasc. II, 185-406, 1855, fasc. III, 407-661. London \& Cambridge.

MorRIS, S.F. 1988. A review of British trilobites, including a synoptic revision of Salter's Monograph. Palaeontographical Society (Monograph) 140,1-316.

Nielsen, A. 1997. A review of Ordovician agnostid genera (Trilobita). Transactions of the Royal Society Edinburgh, Earth Sciences 87, 463-501.

Nielsen, A. 1999. A Catalogue of Ordovician Agnostid Trilobites. Danmarks og Grønlands Geologiske Undersøgelse rapport 1999(24). 199 pp. Copenhagen.

NovÁK, O.P. 1883. Zur Kenntniss der böhmischen Trilobiten. In Beiträge zur Palaeontologie Österreich-Ungarns und des Orients, 22-63.

OLIN, E. 1906. Om de Chasmopskalken och Trinucleusskiffern motsvarende Bildningarne i Skåne. Lunds Universitets Arsskrift N.F. Afdelningen 2, 2(3), 1-79.

Owen, A.W. 1981. The Ashgill trilobites of the Oslo Region, Norway. Palaeontographica, Abteilung A175, 1-88.

Owen, A.W. \& Bruton, D.L. 1980. Late Caradoc-early Ashgill trilobites of the central Oslo Region, Norway. Paleontological Contributions from the University of Oslo 245, 1-42.

Owen, A.W. \& Parkes, M.A. 2000. Trilobite faunas of the Duncannon Group: Caradoc stratigraphy, environments and palaeobiogeography of the Leinster Terrane, Ireland. Palaeontology 43(2), 219-269. DOI 10.1111/1475-4983.00125

Owen, A.W. \& Bruton, D.L. 2008. The environmental significance and fate of the trilobite fauna of the Pyle Mountain Argillite (upper ordovician), Maine, 283-287. In RÁBANO, I., Gozalo Gutiérrez, R. \& García-Bellido, D. (eds) Advances 
in trilobite research. Publicaciones del Instituto Geológico y Minero de España, Cuadernos del Museo Geominero 9. Instituto Geológico y Minero de España, Madrid, Spain.

Owen, A.W. \& Romano, M. In print. Deep shelf trilobite biofacies from the upper Katian (Upper Ordovician) of the Grangegeeth Terrane, eastern Ireland. Geological Journal, 1-12, published on-line. DOI 10.1002/gj.1280

OwEns, R.M. \& Fortey, R.A. 2010. Silicified Upper Ordovician trilobites from Pai-Khoi, Arctic Russia. Palaeontology 52(6), 1209-1220. DOI 10.1111/j.1475-4983.2009.00910.x

PeK, I. 1977. Agnostid trilobites of the Central Bohemian Ordovician. Sborník geologických věd, Paleontologie 19, 7-44.

Pek, I. \& Prokop, R.J. 1984. Nové nálezy agnostidních trilobitů z ordoviku hlavního města Prahy. Časopis Národního muzea, Oddělení přirodovědné 53(1), 17-20.

Peк, I. \& VAnĚK, J. 1989. Index of Bohemian trilobites. 65 pp. Krajské vlastivědné muzeum Olomouc, Olomouc.

Peng, S., Lin, T. \& LI, Y. 2001. Restudy on the trilobites (agnostoids and other polymerids) from the Miaopo Formation (Upper Ordovician) in eastern Yangtze Gorge area, western Hubei. Acta Palaeontologica Sinica 40, 1-19. [in Chinese with English abstract]

Price, D. 1980. The Ordovician trilobite fauna of the Sholeshook Limestone Formation of South Wales. Palaeontology 23(4), 839-887.

PřıBYL, A. 1953. Seznam českých trilobitových rodů (Index) (Index of trilobite genera in Bohemia). Knihovna Ústředního ústavu geologického 25, 1-80. [in Czech, Russian and English]

Pर̌IBYl, A. \& VANĚK, J. 1968. Einige Trilobiten aus dem böhmischen Ordovizium. Věstník Ústředního ústavu geologického 43(3), 191-197.

Qiu, H., Lu, Y., Zhu, Z., Bi, D., Lin, T., Zhou, Z., Zhang, Q., Qian, Y., Ju, T., HAN, N. \& WeI, X. 1983. Trilobita, 28-254. In Palaeontological Atlas of east China I. Geological Publication House, Beijing. [in Chinese]

RAYMOND, P.E. 1925. Some trilobites of the lower Middle Ordovician of eastern North America. Bulletin of the Museum of Comparative Zoology, Harward University 67, 1-180.

REED, F.R.C. 1896. The fauna of the Keisley Limestone. Part I. Quarternal Journal of the Geological Society of London 52, 407-437. DOI 10.1144/GSL.JGS.1896.052.01-04.22

ReED, F.R.C. 1903. The Lower Palaeozoic trilobites of the Girvan, Part 1. Palaeontographical Society (Monograph) 57, $1-48$.

REED, F.R.C. 1931. The Lower Palaeozoic trilobites of the Girvan. Supplement 2. Palaeontographical Society (Monograph) $83,1-30$.

Romano, M. \& Owen, A.W. 1993. Early Caradoc trilobites of eastern Ireland and their palaeogeographic significance. Palaeontology 36, 681-720.

Salter, J.W. 1848. In Phillips, J. \& Salter, J.W. Palaeontological appendix to Professor John Phillips' Memoir on the Malvern Hills compared with the Palaeozoic districts of Abberley etc. Memoir of the Geological Survey of Great Britain 2(1), 331-386.

SHAw, F.C. 2000. Trilobites of the Králův Dvůr Formation (Ordo- vician) of the Prague Basin, Czech Republic. Bulletin of Geosciences 75(4), 371-404.

Shergold, J.H., Laurie, J.R. \& Sun, X. 1990. Classification and review of the trilobite order Agnostida Salter, 1864: an Australian perspective. Bureau of Mineral Resources, Geology and Geophysics, Report 296, 1-93.

ŠNAJDR, M. 1983. Revision of the trilobite type material of I. Hawle and A.J.C. Corda, 1847. Sborník Národního muzea v Praze B39(3), 129-212.

Termier, G. \& Termier, H. 1950. Paleontologie Marocaine, 2, Invertébrés de L'ére Primaire. Actualités scientifiques et industrielles 1095, 1-279.

Thoral, M. 1933. Contribution à l'étude paléontologique de l'Ordovicien inférieur de la Montagne Noire et revision sommaire de la faune cambrienne de la Montagne Noire. 362 pp. Imprimerie de la Charité, Montpellier.

TomCZyKova, E., JAGIELSKA, L. \& NeHRING, M. 1972. Ordovician, 29-46. In Czerminski, J. \& Pajchlowa, M. (eds) Geology of Poland, volume II, Catalogue of Fossils, Part 1, Paleozoic. Wydawnictwa Geologiczne, Warszaw.

Turvey, S.T. 2005. Agnostid trilobites from the Arenig-Llanvirn of South China. Transactions of the Royal Society of Edinburgh, Earth Sciences 95, 527-542 (for 2004).

VANĚK, J. \& VALÍČEK, J. 2001. New index of the genera, subgenera, and species of Barrandian trilobites. Part A-B (Cambrian and Ordovician). Palaeontologia Bohemiae 7(1), 1-49.

VANĚK, J. \& VOKÁČ, V. 1997. Trilobites of the Bohdalec Formation (Upper Berounian, Ordovician, Prague Basin): Czech Republic. Palaeontologia Bohemiae 3, 20-50.

Villas, E., Hammann, W. \& Harper, A.T. 2002. Foliomena Fauna (Brachiopoda) from the Upper Ordovician of Sardinia. Palaeontology 45(2), 267-295.

DOI 10.1111/1475-4983.00237

WANDÅs, B.T.G. 1984. The Middle Ordovician of the Oslo Region, Norway. 33. Trilobites from the lowermost part of the Ogygiocaris Series. Norsk geologisk Tidsskrift 63, 211-267.

Whittington, H.B. 1950. Sixteen Ordovician genotype trilobites. Journal of Paleontology 24(5), 531-565.

Whittington, H.B. 1965. Trilobites of the Ordovician Table Head Formation, Western Newfoundland. Bulletin of the Museum of Comparative Zoology, Harvard University 132, 281-442.

Whittington, H.B. 1968. The Ordovician trilobites of the Bala area, Merioneth. IV. Palaeontographical Society (Monograph) 122, 93-138.

Whittington, H.B., Chang, W.T., Dean, W.T., Fortey, R.A., Jell, P.A., Laurie, J.R., Palmer, A.R., Repina, L.N., RushTON, A.W.A. \& SHERGOLD, J.H. 1997. Systematic description of the class Trilobita - Suborder Agnostina, O331-O383. In MoOre, R.C. \& KAESLER, R.L. (eds) Treatise on Invertebrate Paleontology, Part O, Arthropoda 1, Trilobita, Revised. Lawrence, Kansas.

Zноu Zнгуі 1987. Notes on Chinese Ordovician Agnostids. Acta Palaeontologica Sinica 26(6), 639-661.

Zhou Zhiу \& Dean, W.T. 1986. Ordovician trilobites from Chedao, Gansu Province, North-west China. Palaeontology 29(4), 743-786. 